\title{
Dietary Fatty Acids and Predementia Syndromes
}

\author{
Vincenzo Solfrizzi $i^{1, \star}$, Vincenza Frisardi ${ }^{1}$, Cristiano Capurso ${ }^{2}$, \\ Alessia D'Introno ${ }^{1}$, Anna M. Colacicco ${ }^{1}$, Gianluigi Vendemiale ${ }^{2,3}$, \\ Antonio Capurso ${ }^{1}$, and Francesco Panza ${ }^{1}$ \\ ${ }^{1}$ Department of Geriatrics, Center for Aging Brain, Memory Unit, University of Bari, \\ Italy; ${ }^{2}$ Department of Geriatrics, University of Foggia, Italy; ${ }^{3}$ Internal Medicine Unit, \\ IRCSS Casa Sollievo dalla Sofferenza, San Giovanni Rotondo, Italy
}

E-mail: v.solfrizzi@geriatria.uniba.it; eziafrisardi@yahoo.it; c.capurso@unifg.it; geriat.spec@geriatria.uniba.it; am.colacicco@geriatria.uniba.it; g.vendemiale@unifg.it; a.capurso@geriatria.uniba.it; geriat.dot@geriatria.uniba.it

Received April 17, 2009; Revised June 10, 2009; Accepted June 24, 2009; Published August 11, 2009

An increasing body of epidemiological evidence suggests that elevated saturated fatty acids (SFA) could have negative effects on age-related cognitive decline (ARCD). Furthermore, a reduction of risk for cognitive decline and mild cognitive impairment $(\mathrm{MCl})$ has been found in population samples with elevated fish consumption, and high intake of monounsaturated fatty acids (MUFA) and polyunsaturated fatty acids (PUFA), particularly n-3 PUFA. However, recent findings from clinical trials with n-3 PUFA supplementation showed efficacy on depressive symptoms in non-apolipoprotein $E$ (APOE) $\varepsilon 4$ carriers, and on cognitive symptoms only in very mild Alzheimer's disease (AD) subgroups, $\mathrm{MCl}$ patients, and cognitively unimpaired non-APOE $\varepsilon 4$ carriers. These data, together with epidemiological evidence, support the idea that n-3 PUFA may play a role in maintaining adequate cognitive functioning in predementia syndromes, but not when the AD process has already taken over. Therefore, at present, no definitive dietary recommendations on fish and unsaturated fatty acids consumption, or lower intake of saturated fat, in relation to the risk for dementia and cognitive decline are possible.

KEYWORDS: MUFA, PUFA, fatty acids, predementia syndromes, dementia, Alzheimer's disease, vascular dementia, mild cognitive impairment, age-related cognitive decline

\section{INTRODUCTION}

Clinical and epidemiological research has focused on the identification of risk factors that may be modified in predementia syndromes, at a preclinical or early clinical stage of dementing disorders. In recent years, in an effort to identify clinical targets of potential therapeutic agents for Alzheimer's disease (AD), people with mild cognitive impairment (MCI) have been enrolled in trials with drugs that were tested in patients with $\mathrm{AD}[1]$. However, previous studies have shown that not all MCI subjects have predementia $\mathrm{AD}[2]$. The umbrella term "predementia syndromes" includes the transitional phase between mild nondisabling cognitive decline and disabling dementia, an ambiguous diagnostic period during which it is unclear whether mild cognitive deficits predict incipient dementia or not. In fact, the clinical 
label identifies all conditions with age-related deficits in cognitive function reported in the literature, including a mild stage of cognitive impairment based on a normality model and pathological conditions considered predictive of early stages of dementia[2,3]. Such predementia syndromes have been defined for $\mathrm{AD}$ and partly for vascular dementia $(\mathrm{VaD})$, but have not yet been operationalized for other specific forms of dementia.

\section{Definition of Predementia Syndromes}

The term "predementia syndromes" includes different conditions and among them, MCI is, at present, the most widely used term to indicate nondemented, aged persons with no significant disability, and a mild memory or cognitive impairment that cannot be explained by any recognized medical or psychiatric condition[2,3]. At present, the term mild cognitive impairment and its acronym MCI have frequently been used in studies on the preclinical phases of dementia, although with differing and inconsistent definitions $[4,5,6,7]$. There is now ample evidence that MCI is often a pathology-based condition with a high rate of progression to $\mathrm{AD}[2,3]$. Therefore, $\mathrm{MCI}$ has also been identified as the predementia syndrome for AD. The more recently proposed multiple subtypes of MCI were intended to reflect the heterogeneity of different types of dementia. Actually, there are at least three different subclassifications of MCI according to its cognitive features[8], clinical presentation[7], and probable etiology[9]. MCI definitions can be broadly classified as amnestic (aMCI) and nonamnestic (naMCI). A critical review was recently made in Stockholm and then in Montreal, in order to define a new consensus on MCI[7]. Modification of Petersen's criteria[6] was proposed during the conference in Montreal. Lastly, the European Consortium on Alzheimer's Disease (EADC) working group on MCI very recently proposed a novel diagnostic procedure with different stages, combining neuropsychological evaluation and family interview to detect MCI at the earliest possible stage[10]. Furthermore, different diagnostic criteria have been proposed for other predementia syndromes, and the terms age-related cognitive decline (ARCD)[11] and aging-associated cognitive decline (AACD)[12] have recently been proposed to distinguish individuals with mild cognitive disorders associated with aging, and nonpathologically based from noncognitively unimpaired individuals.

The causes of predementia syndromes and dementia are unknown at present. However, some studies have suggested that these conditions may be prevented[13,14]. The role of the diet in cognitive decline has not been investigated extensively, with a few data available on the role of macronutrient intake in the pathogenesis of predementia and dementia syndromes[13,14]. Since several dietary factors affect the risk of cardiovascular disease, it can be assumed that they also influence the risk of dementia[15]. Some recent studies have suggested that dietary fatty acids may play a role in the development of cognitive decline associated with aging or dementia[16]. This concept is further supported by recent evidence that certain diets have been associated with a lower incidence of AD. In fact, antioxidants, dietary fatty acids, and micronutrients appear to have a role, and evidence is at least suggestive that diets rich in fruits and vegetables and other dietary approaches may permit a beneficial effect on the risk of dementia[13,14].

Fatty acids can be categorized briefly into saturated fatty acids (SFA) and unsaturated fatty acids (UFA). SFA, such as stearic acid, are present in products such as meat, dairy products, cookies, and pastries. Monounsaturated fatty acids (MUFA) are most frequently consumed via olive oil. The principal series of polyunsaturated fatty acids (PUFA) are n-6 (i.e., linoleic acid) and n-3 (i.e., $\alpha$-linolenic acid, docosahexaenoic acid [DHA], and eicosapentaenoic acid [EPA]). In our Mediterranean dietary pattern, the main sources of n-6 PUFA are vegetable oils, while the principal sources of n-3 PUFA are fatty fish (salmon, tuna, and mackerel). In fact, olive oil contains 70-80\% MUFA (oleic acid) and 8-10\% PUFA (6-7\% linoleic acid and 1-2\% $\alpha$-linolenic acid)[16]. The aim of this article was to examine the possible role of dietary fatty acids in modulating the risk of age-related changes in cognitive function and predementia syndromes, as well as the possible mechanisms behind the observed associations. 
Furthermore, we reviewed current evidence on dietary fatty acid supplementation in predementia and dementia syndromes.

\section{Dietary Fatty Acids in ARCD and Predementia Syndromes: Cross-Sectional Studies}

At present, an increasing number of epidemiological and clinical studies have addressed the link between UFA intake and cognitive function, most being cross-sectional[16]. In the last years, the study approach was to associate single micro- or macronutrients to ARCD, MCI, AD, or VaD. In this picture, several hallmarks of the Mediterranean diet were linked to increased risk or with a protective effect against cognitive impairment[17]. The typical dietary pattern of the Mediterranean diet is characterized by high intakes of vegetables, fruits and nuts, legumes, cereals, fish, and MUFA; relatively low intakes of meat, and dairy products; and moderate consumption of alcohol. In fact, higher levels of consumption of olive oil are considered the hallmark of the traditional Mediterranean diet.

In a cross-sectional French study on 441 free-living elderly subjects aged 65 or over, a positive relationship was found in women between lipid intake and the Mini-Mental State Examination (MMSE) score, which evaluates global cognitive functions. A positive relationship was also found between PUFA intake and mobility in men, and between functional variables and alcohol intake in the whole sample. The response rate of this study was very low (around 50\%) and these findings, contradictory to the results of the subsequent studies, were explained by the authors with the fact that high intakes of these dietary factors can be considered as an indicator of a better health status[18] (Table 1, see pp. 10-15). Another cross-sectional study from Spain investigated the association between dietary intake and global cognitive functions, assessed by the MMSE and the Pfeiffer's Mental State Questionnaire (PMSQ), among 260 noninstitutionalized and nondemented older subjects, aged 65-90 years. The subjects with a lower intake of MUFA, SFA, and cholesterol, and higher intakes of total calories, fresh fruit, carbohydrate, thiamine, foliate, vitamin $\mathrm{C}$, and minerals (iron and zinc), had the best performance in cognitive tests (MMSE score $>28$ points or no errors on the PMSQ), with a statistical significance after adjustment for age and sex[19] (Table 1).

As seen above, MUFA, consequently to the high consumption of extra-virgin olive oil, represent the most important fats in the Mediterranean diet. Cumulative evidence suggests that extra-virgin olive oil may have a role in the protection against cognitive decline, other than against coronary disease and several types of cancer because of its high levels of MUFA and polyphenolic compounds. The crosssectional association between dietary macronutrients and cognitive impairment was examined in 278 nondemented elderly subjects, aged 65-84 years, from the Italian Longitudinal Study on Aging (ILSA). A large, population-based, prospective study, with a sample of 5,632 subjects, 65-84 years old, independent or institutionalized, were randomly selected from the electoral rolls of eight Italian municipalities after stratification for age and gender. After adjustment for educational level, the odds ratios (ORs) of cognitive decline (MMSE score <24) decreased exponentially with the increase of MUFA energy intakes. Despite the lower education ( $\leq 3$ years), MUFA energy intake over 2,400 kJ/day was associated with a reduction in OR of cognitive impairment. The age as a confounder of the interaction term "education by MUFA" was associated with a further increase in OR of cognitive impairment. Furthermore, selective attention performances were independently associated with MUFA intake[20] (Table 1). Recently, another Northern Italian cross-sectional study examined whether type of dietary fats consumed was associated with cognitive performance in a sample of 191 subjects, aged 65 years and older, randomly selected from a free-living population from the Progetto Veneto Anziani (Pro.V.A. study)[21] (Table 1). Global cognitive functions were assessed with the MMSE, comparing subjects with a score between 10 and 17 with subjects with a score between 28 and 30, and plasma phospholipid fatty acid composition was determined by using gas chromatography. In the Pro.V.A. study, in a multiple regression analysis, age and educational level accounted for $29.6 \%$ of the MMSE variance, while the contribution of the other variables considered (low-density lipoproteins [LDL] cholesterol, diastolic blood pressure, MUFA, and 
PUFA) was almost negligible[21]. The authors acknowledged that these results were limited by the fact that total energy intake, which is known to be reduced in patients with cognitive impairment, was not considered, and by the fact that the study was a cross-sectional survey. Recently, in the Doetinchem Cohort Study, after adjusting for age, gender, education, alcohol consumption, smoking, and energy intake, higher dietary cholesterol was associated with an increased risk of impaired memory function and cognitive flexibility, whereas higher SFA intake was associated with an increased risk of impairment in memory function, psychomotor speed, and cognitive flexibility by $15-19 \%$, although not significantly. Fatty fish and marine n-3 PUFA consumption were significantly associated with a decreased risk of global cognitive function impairment and psychomotor speed by 19-28\%. These associations appeared to be independent of differences in cardiovascular risk factors[22] (Table 1). Moreover, Conquer and colleagues measured the plasma fatty acid composition of various phospholipids in blood samples from 84 subjects with different degrees of cognitive impairment, including AD and other types of dementia. Without considering confounding factors, this study showed a statistically significant lower level of n-3 PUFA in the plasma of subjects with cognitive impairment[23].

\section{Dietary Fatty Acids in ARCD and Predementia Syndromes: Longitudinal Studies}

To our knowledge, there is an increasing number of longitudinal epidemiological studies on the association between fatty acids and cognitive functioning[16,24,25,26,27,28,29,30,31], indicating a crucial need for prospective studies that could confirm initial observations. In particular, one of these prospective studies, the Zutphen Study of 476 men aged 69-89 years, found that high linoleic acid intake was positively associated with cognitive impairment in elderly subjects only in cross-sectional study after an adjustment for age, education, cigarette smoking, alcohol consumption, and energy intake. High fish consumption tended to be inversely associated with cognitive impairment and cognitive decline at 3-year follow-up, but not significantly[24] (Table 1). Furthermore, in the cohort of the Etude du Viellissement Arteriel (EVA) Study, moderate cognitive decline (a >2-point decrease on the MMSE) and erythrocyte membrane fatty acid composition were evaluated in 246 elderly subjects aged 63-74 years, during a 4year follow-up. In this study, a lower content of n-3 PUFA was significantly associated with a higher risk of cognitive decline. After adjusting for age, gender, educational level, and initial MMSE score, stearic acid and total n-6 PUFA were consistently associated with an increased risk of cognitive decline. Moreover, a lower content of n-3 PUFA was significantly associated with cognitive decline, but after adjustment, this association remained significant only for DHA and not for EPA[25] (Table 1). Findings from the Chicago Health and Aging Project (CHAP), on 2,560 persons aged 65 years and older, showed that in a large population-based sample, a high intake of saturated and trans-unsaturated fat was associated with a greater cognitive decline over a 6-year follow-up. Intake of MUFA was inversely associated with cognitive change among persons with good cognitive function at baseline and among those with stable long-term consumption of margarine, a major food source. Slower decline in cognitive function was associated with higher intake of PUFA, but the association appeared to be due largely to its high content of vitamin $\mathrm{E}$, which shares vegetable oil as a primary food source and which is inversely related to cognitive decline. Finally, cognitive change was not associated with intakes of total fat, animal fat, vegetable fat, or cholesterol[26] (Table 1). In the same CHAP sample, on 3,718 persons aged 65 years and older, high copper intake was associated with a significantly faster rate of cognitive decline, but only among persons who also consumed a diet that was high in saturated and trans fats in a 6-year followup[27] (Table 1). Moreover, in a total of 732 men and women, 60 years or older, participating in the EPIC-Greece cohort (European Prospective Investigation into Cancer and Nutrition) and residing in the Attica region, six to 13 years later, seed oil consumption may have adversely affected cognition, whereas adherence to the Mediterranean diet, as well as intake of olive oil, MUFA, and SFA exhibited weakly positive, but not significant associations[28] (Table 1). Finally, 4,809 elderly women (born between 1925 and 1930) were studied in a French longitudinal cohort, the Etude Epidémiologique de Femmes de la Mutuelle Générale de l'Education Nationale (E3N) study. Elderly women participating in the E3N cohort 
that were reported by informants to have undergone recent cognitive decline had, 13 years previously, lower intakes of poultry, fish, and animal fats, as well as higher intakes of dairy desserts and ice cream. They had lower habitual intakes of dietary fiber and n-3 PUFA, but a higher intake of retinol. Furthermore, elderly women that were reported by informants to be functionally impaired had, in the past, lower intakes of vegetables and vitamins B2, B6, and B12[29] (Table 1).

Therefore, on the basis of the previous significant suggestions[16], we tested further the hypothesis that high MUFA and PUFA intakes may protect against the development of cognitive impairment over time in a median follow-up of 8.5 years of the ILSA. The major finding of this study was that high MUFA, PUFA, and total energy intake were significantly associated with a better cognitive performance in time. Total energy intake should be considered an important confounder of diet-ARCD relationships and, as we proposed in our methodological approach, suggest that association between macronutrient intake and cognitive decline should be adjusted by total energy intake. No other individual dietary components of our study population was significantly associated with cognitive impairment in time[30] (Table 1). The association between high MUFA and PUFA intakes and cognitive performance remained robust even after adjustment for potential confounding variables, such as age, sex, educational level, Charlson Comorbidity Index, body mass index, and total energy intakes[30]. Finally, recent findings from the ILSA demonstrated that while dietary fatty acid intakes were not associated with incident MCI, high PUFA intake appeared to have a borderline nonsignificant trend for a protective effect against the development of MCI[31] (Table 1).

\section{Fish Consumption in ARCD and Predementia Syndromes}

Epidemiological observational studies reporting associations of fish consumption with cognitive function have shown mixed results; some cross-sectional and longitudinal studies have reported a positive association with higher fish consumption[32,33,34,35], while others have found no association[36,37] (Table 1). Fish, particularly fatty fish (e.g., herring, mackerel, salmon, or trout), is the principal source of n-3 PUFA in the Mediterranean diet. Very recently, the baseline data from the Older People And n-3 Long-chain polyunsaturated fatty acid (OPAL) study, a double-blind, randomized, placebo-controlled trial examining the effect of daily supplementation with $700 \mathrm{mg} \mathrm{n}-3$ PUFA (500 mg DHA and $200 \mathrm{mg}$ EPA) for 24 months on cognitive performance in healthy older persons aged 70-79, suggested that higher fish consumption is associated with better cognitive function in later life[32]. Of particular interest was the apparent linear trend for increased cognitive function across the five-item fish consumption variable, with highest cognitive function levels found in those individuals who report eating the largest amount of fatty, as opposed to white, fish[32] (Table 1). In the CHAP, the large population-based sample of 3,718 persons aged 65 years and older, dietary intake of fish was inversely associated with cognitive decline over 6 years of follow-up. In this cohort, there was little evidence that the n-3 PUFA were associated with cognitive change[33] (Table 1). Furthermore, in 210 participants in the Zutphen Elderly Study aged 7089 years, fish consumers had significantly less 5-year subsequent cognitive decline than did nonconsumers. A linear trend was observed for the relation between the intake of EPA + DHA and cognitive decline, and an average difference of $380 \mathrm{mg} / \mathrm{day}$ in EPA + DHA intake was associated with a 1.1-point difference in cognitive decline[34] (Table 1). Finally, findings from the Hordaland Health Study, 2,031 subjects aged 70-74 years from the general population in Western Norway, suggested that subjects whose mean daily intake of fish and fish products was $>10 \mathrm{~g} /$ day had significantly better mean test scores and a lower prevalence of poor cognitive performance than did those whose intake was $<10$ $\mathrm{g} /$ day. The associations between total intake of seafood and cognition were strongly dose dependent; the maximum effect was observed at an intake of $75 \mathrm{~g} /$ day. The effect was more pronounced for nonprocessed lean fish and fatty fish[35] (Table 1). 


\section{DIETARY FATTY ACID SUPPLEMENTATION IN PREDEMENTIA SYNDROMES: IS IT THE CASE FOR A TREATMENT?}

The increasing epidemiological evidence of an association between a reduced risk of AD and a diet high in n-3 PUFA and fish consumption[17] is further supported by recent findings that certain diets have been associated with a lower incidence of predementia syndromes[30,31]. One randomized clinical trial (RCT), using an n-3/n-6 fatty acid compound for 4 weeks in 100 AD patients (60 received the fatty acid compound and 40 a placebo control), found improvements in mood, cooperation, appetite, sleep, ability to navigate in the home, and short-term memory[37]. Furthermore, another RCT assessed the effect of supplementation with DHA on cognitive function among 20 elderly nursing home residents with VaD. Hasegawa's Dementia Scale - Revised (HDS-R) and MMSE scores improved in the DHA-treated group, but not among patients who were not treated with DHA. Comparisons between groups were significant at 3 and 6 months for the HDS-R and at 6 months for the MMSE[38].

Recently, Freund-Levi and colleagues examined the effects of dietary n-3 PUFA supplementation, randomizing 204 patients with moderate $\mathrm{AD}$ to receive DHA and EPA (for a total dose of 1,720 mg DHA/600 mg EPA) or placebo for 6 months (OmegAD Study). After the treatment period, all the subjects received open-label n-3 PUFA for another 6 months. The authors found that the supplementation did not delay the rate of cognitive decline but, in the group of 32 patients with the most mild AD (MMSE > 27, Clinical Dementia Rating Score 0.5-1), n-3 PUFA supplementation slowed the decline in MMSE scores[39]. In addition, the subjects in the placebo group of these very mild AD patients also showed a statistically significant slowing of decline when they were switched to treatment between 6 and 12 months, suggesting that n-3 PUFA might be of benefit to slow the progression of the disease in MCI or very mild $\mathrm{AD}$ [39]. Furthermore, this supplementation did not result in marked effects on neuropsychiatric symptoms in mild to moderate AD patients, except for possible positive effects on depressive symptoms and agitation symptoms in subgroups[40]. In fact, there were positive effects on depressive symptoms in non-APOE (non-apolipoprotein E) $\varepsilon 4$ carriers and in non-APOE $\varepsilon 4$ carriers on agitation symptoms[40].

At present, the effect of arachidonic acid and DHA (240 mg/day) after a 90-day supplementation on $\mathrm{MCI}$, organic brain lesions, or $\mathrm{AD}$ showed a significant improvement of the immediate memory and attention score for MCI patients, and a significant improvement of immediate and delayed memories for patients with organic brain damages[41]. The AD group showed no improvement after the supplementation of arachidonic acid and DHA, and the placebo group showed no significant improvement of cognitive functions by the supplementation of $240 \mathrm{mg} /$ day of olive oil (high MUFA content)[41]. The lack of cognitive effects of the olive oil supplementation may probably be explained by the very small amount of olive oil administered in comparison with our ILSA sample in which the mean consumption of olive oil was particularly high: $46 \mathrm{~g} /$ day (12.6-113.1 g/day)[20]. Finally, the preliminary results from a 24-week, randomized, double-blind, placebo-controlled study on 23 participants with mild or moderate $\mathrm{AD}$ and 23 with MCI randomized to receive $\mathrm{n}-3$ PUFA $1.8 \mathrm{~g} /$ day or placebo (olive oil), suggested that n-3 PUFA monotherapy was well tolerable for most of the participants with AD or MCI[42]. This supplementation may improve global clinical function, as measured by the Clinician's Interview-Based Impression of Change scale, which included caregiver-supplied information (CIBICplus), relative to placebo. No associations were found between the randomization group and Alzheimer's Disease Assessment Scale - cognitive (ADAS-cog), MMSE, or Hamilton Depression Rating Scale scores. Levels of EPA on erythrocyte membrane were associated with cognitive function, measured by ADAS$\operatorname{cog}$, in these patients[42]. However, in a secondary analysis, participants with MCI showed more improvement of ADAS-cog than those with AD associated with n-3 PUFA administration[42], supporting recent reports in which PUFA supplementation could be more effective on cognition in people with very mild $\mathrm{AD}[39]$ or $\mathrm{MCI}[41]$.

In 2006, a Cochrane review team was unable to locate a single published RCT on which to base recommendations for the use of dietary or supplemental n-3 PUFA for the prevention of cognitive impairment or dementia[43]. However, very recently, in a randomized, double-blind, placebo-controlled 
trial on 302 cognitively healthy (MMSE score >21) individuals aged 65 years or older, the possible impact of n-3 PUFA on the mental well-being and cognitive performance of nondepressed (Center for Epidemiologic Studies Depression Scale score <16), older individuals was investigated[44,45]. In this RCT, participants were randomly assigned to 1,800 mg/d EPA-DHA, $400 \mathrm{mg} /$ day EPA-DHA, or placebo capsules for 26 weeks[44,45]. In older Dutch subjects, no effect of daily supplementation with low or high doses of EPA-DHA on mental well-being as assessed by depression and anxiety questionnaires was found[44]. Furthermore, there were no significant differential changes in any of the cognitive domains (attention, sensorimotor speed, memory, and executive function) for either low- or high-dose fish oil supplementation compared with placebo[45]. However, an effect of EPA-DHA supplementation in subjects who carried the APOE $\varepsilon 4$ allele was found, but only on the cognitive domain of attention[45]. Fish oil may be beneficial in those subjects who are most sensitive to developing dementia. These two substantially negative studies on ARCD may be explained by the samples investigated (nondepressed and noncognitively impaired older subjects). Further trials in depressed patients or $\varepsilon 4$ carriers with MCI are needed. Finally, there is another ongoing RCT with cognitive end points of n-3 PUFA supplementation in healthy, cognitively intact, older persons. The OPAL study examined healthy older persons aged 70-79 with good cognitive function (MMSE $\geq 24$ out of 30 points at baseline) who are recruited from 20 primary care practices[46].The OPAL study was completed at the end of 2007 and findings will be published shortly. Therefore, epidemiological evidence suggested a possible association between PUFA (particularly, n-3 PUFA) and reduced risk of cognitive decline and dementia. However, due to the small number of studies that inform about this topic, further research is necessary before a strong conclusion can be drawn. Some recent RCTs assessed the cognitive or functional effect of n-3 PUFA supplementation on patients with $\mathrm{VaD}, \mathrm{AD}, \mathrm{MCI}$, or $\mathrm{ARCD}$ in cognitively unimpaired older subjects. These RCTs suggested a positive effect of this intervention only in very mild AD or MCI patients, or in subgroups (e.g., APOE e4 carriers) for cognitive performance in nondemented subjects or for neuropsychiatric symptoms in mild to moderate AD patients. Supplemental DHA may not necessarily be recommended when the decline is more severe, possibly because additional DHA might contribute to degenerative processes in the brain related to lipid peroxidation. Furthermore, the breadth of doses of DHA used in these studies covered a 36-fold range (from $120 \mathrm{mg} /$ day to $4.3 \mathrm{~g} /$ day), a huge range that, importantly, produced no apparent dose-related effects on cognition. On the basis of these evidences, we also strongly suggest for predementia syndromes, a high-risk condition for progression to dementia of vascular and degenerative origin, intervention trials using measures of dietary supplementation similar to the OmegAD Study in order to determine if such supplements will slow cognitive decline[47].

\section{FATTY ACIDS AND COGNITIVE DECLINE: POSSIBLE MECHANISMS}

Different pathways could contribute to the neuroprotective as well as the neurotrophic properties of UFA[48,49]. In the older subjects of the ILSA, which fulfilled a Mediterranean dietary pattern, total fat is $29 \%$ of energy, with a high consumption of olive oil (46 g/day), a MUFA energy intake of $17.6 \%$ of total energy, $85 \%$ of which derived from olive oil, and a SFA intake of only 6\%[20]. In our population, the prolonged protection of MUFA intake against age-related changes in cognitive functions may be linked to the relevant quota of antioxidant compounds in olive oil, including low molecular weight phenols[20]. In fact, animal studies suggested that diets high in antioxidant-rich foods, such as spinach, strawberries, and blueberries, rich in anthocyanins and other flavonoids, may be beneficial in slowing ARCD[50]. The possible role of antioxidant compounds from olive oil do not diminish or otherwise alter the argument concerning the fatty acids, because this is only a possible explanation of the role of MUFA on age-related cognitive changes in our population, in which MUFA intake derived for a large part from olive oil.

In adult rats, learning and cognitive behavior are related to brain DHA status, which, in turn, is related to the levels of the dietary n-3 PUFA[51]. In fact, administration of DHA seems to improve learning ability in $\beta$-amyloid (A $\beta$ )-infused rats[52] and inhibit decline in avoidance-learning ability in the AD model rats, associated with an increase in the cortico-hippocampal n-3/n- 6 ratio, and a decrease in 
neuronal apoptotic products[53]. Similarly, recent studies showed that dietary DHA in an aged AD mouse model could be protective against $\mathrm{A} \beta$ production, deposition in plaques and cerebral amyloid angiopathy[54,55], and increases cerebral blood volume[55]. In other transgenic AD mouse models, DHA also protects against dendritic pathology[56] and prevents neuronal apoptosis induced by soluble $A \beta$ peptides[57], increases synaptic protein and phospholipid densities[58,59], and inhibits degradative endopeptidase activities[60]. Some experimental evidence suggested that essential n-3 PUFA effectively lower $A \beta$ production in transgenic mice, as reported in studies from several laboratories $[54,58,61]$. Yet, plaque burden was reduced in one study using aged transgenic mice following a 3-month DHA-enriched diet[54], but not in other studies that started dietary intervention at a much younger age[55,61].

The neuroprotective effects of dietary UFA could rely on their impact on membrane architecture. In fact, UFA have an important role in maintaining the structural integrity of neuronal membranes, determining the fluidity of synaptosomal membranes, and thereby regulating neuronal transmission. Furthermore, essential fatty acids can modify the activity of certain membrane-bound enzymes (phospholipase A2, protein kinase C, and acetyltranferase) and the function of the neurotransmitters' receptors. Finally, free fatty acids, lipid metabolites, and phospholipids modify the function of membrane proteins, including ion channels[62]. Moreover, fatty acid composition of neuronal membranes in advancing age demonstrated an increase in MUFA content and a decrease in PUFA content[63]. n-3 PUFA increase membrane fluidity by replacing n-6 PUFA and cholesterol from the membrane[64], maintaining an optimal membrane fluidity as obligatory for neurotransmitter binding and signaling within the cell[65]. There is also evidence that associates a dietary deficiency of n-3 PUFA with changes in cortical dopaminergic function[66]. The n-3 PUFA from fish may be inversely associated with dementia because it lowers the risk of thrombosis[67], stroke[68], cardiovascular disease[69], and cardiac arrhythmia, reducing the risk of thromboembolism in the brain and consequently of lacunar and large infarcts that can lead to VaD and AD. Furthermore, the n-3 PUFA may be as important as lipids in the brain, particularly for the possible influence of DHA on the physical properties of the brain that are essential for its function[70]. Furthermore, fish oil was a better source than $\alpha$-linolenic acid for the incorporation of n-3 PUFA into rat brain phospholipid subclasses[62]. Conversely, high linoleic acid intake (n-6 PUFA) may increase the susceptibility of LDL cholesterol to oxidation, which makes it more atherogenic[71], even if the association between linoleic acid and atherosclerosis is controversial[72]. Therefore, the ratio of dietary n-3/n-6 PUFA intake may influence the potential role of PUFA on cognitive decline and dementia, the optimal ratio of n-6/n-3 for an healthier diet should be $<5: 1[73]$. Finally, a high dietary intake of SFA and cholesterol increases the risk for cardiovascular disease, and therefore for cognitive decline, $\mathrm{VaD}$, and $\mathrm{AD}$ [13]. Conversely, treatment for 4 weeks with a Mediterranean-inspired diet rich in n-3 PUFA decreased blood lipids in healthy individuals with a lowrisk profile for cardiovascular disease, with a beneficial effect also on vascular function and oxidative stress[74].

\section{CONCLUSIONS}

At present, several studies suggest that an increase of SFA could have negative effects on cognitive functions. Furthermore, a clear reduction of risk for cognitive decline has been found in population samples with elevated fish consumption, and high intake of MUFA and PUFA, particularly n-3 PUFA. Recent findings demonstrated that while dietary fatty acid intakes were not associated with incident MCI, high PUFA intake appeared to have a borderline nonsignificant trend for a protective effect against the development of MCI. Nonetheless, at present, no definitive dietary recommendations on fish and UFA consumption, or lower intake of saturated fat, in relation to the risk for dementia and cognitive decline are possible. In fact, in a recent RCT, n-3 PUFA supplementation did not influence cognitive functioning during a follow-up of 6 months, except in a small group of patients with very mild AD and for possible positive effects on depressive symptoms in non-APOE $\varepsilon 4$ carriers. These data, together with 
epidemiological evidence, support the idea that n-3 PUFA may have a role in the primary and maybe secondary prevention of the disease, but not when the disease process has already taken over[75]. However, high levels of consumption of fats from fish, vegetable oils, and vegetables should be encouraged because this dietary advice is in accordance with recommendations for lowering the risk of cardiovascular disease, obesity, diabetes, and hypertension. Therefore, epidemiological studies on the association between diet and cognitive decline suggested a possible role of fatty acid intake in maintaining adequate cognitive functioning, and possibly in preventing or delaying the onset of dementia, both of degenerative or vascular origin. Appropriate dietary measures or supplementation with specific macronutrients might open new ways for the prevention and management of cognitive decline and dementia[76].

On the other hand, Scarmeas and colleagues, using the inclusive dietary score (MeDi score), but studying a population with a substantial difference in dietary habits in comparison with Greek (EPIC)[28] and Italian (ILSA)[30,31] cohorts, found that higher adherence to the Mediterranean diet is associated with a trend for reduced risk of incident MCI and with reduced risk of MCI progression to AD[77]. The use of diet scoring systems, such as the MeDi score[78], has undeniable advantages in furthering the understanding of the role of diet in chronic disease[79]. They may account for the complex biologic interactions between different components of a composite dietary pattern, such as Mediterranean diet, that may be difficult to detect in analyses focusing only on the individual components[80]. These contrasting findings about the impact of the MeDi score or individual macronutrients on ARCD or MCI may suggest an approach not confined only to cognitive skills, but extended to functional status and comorbidity. However, we should not renounce a priori the work for a correct estimate of the validity of the MeDi score for cognitive impairment as a criterion. In fact, the evidence about the role of the whole Mediterranean diet on cognitive decline is still scarce[33,77]. Therefore, in future studies, it could also be indicated, together with measures of this effect by a dietary composite score, that the estimates and the impact of the individual components of the diet be reported. In a very recent reanalysis from the ILSA cohort, we showed that high PUFA were associated with reduced risk of incident MCI among those who consumed a low MUFA/SFA ratio intake[81]. In fact, while an increasing body of evidence suggested that elevated fish consumption and high intake of n-3 PUFA may be protective against ARCD and MCI, the traditional Cretan diet, although strongly dependent on high olive oil intake, was never centered on fish consumption[79]. In this context, n-6 PUFA could potentially exert some health benefits. In fact, in the Mediterranean diet, some foods are rich in n-6 PUFA (e.g., walnuts, almonds, hazelnuts), while other foods, although poor in n-6 PUFA, are highly consumed, such as cereals, legumes, and, in less amounts, some types of meat (pork) and poultry. Furthermore, olive oil contains n-6 and n-3 PUFAs in a ratio of 10:1. Therefore, it should be advisable to include PUFA in the MeDi score as individual macronutrients (such as MUFA/SFA ratio), among the components presumed to be beneficial, in evaluating the relationship between adherence to the Mediterranean diet and ARCD or MCI[81].

\section{ACKNOWLEDGMENTS}

This work was supported by the Italian Longitudinal Study on Aging (ILSA) (Italian National Research Council - CNR-Targeted Project on Ageing - Grants 9400419PF40 and 95973PF40) (Dr. Solfrizzi Dr. C. Capurso, Dr. D'Introno, Dr. Colacicco, Pr. A. Capurso, and Dr. Panza). The authors thank Ms. Maria Mann for editing the manuscript. 
TABLE 1

Principal Cross-Sectional and Longitudinal Clinical and Epidemiological Studies on the Relationships between Dietary Fatty Acids or Fish Consumption and Predementia Syndromes (i.e., ARCD and $\mathrm{MCl}$ ) in Older People

\begin{tabular}{|c|c|c|c|c|c|c|}
\hline Ref. & $\begin{array}{l}\text { Setting } \\
\text { and Study } \\
\text { Design }\end{array}$ & Subjects & $\begin{array}{c}\text { Dietary } \\
\text { Assessment }\end{array}$ & $\begin{array}{l}\text { Cognitive } \\
\text { Outcomes }\end{array}$ & $\begin{array}{l}\text { Results and } \\
\text { Conclusions }\end{array}$ & Comment \\
\hline \multicolumn{7}{|c|}{ Cross-sectional studies } \\
\hline $\begin{array}{l}\text { Pradignac et } \\
\text { al.[18] }\end{array}$ & $\begin{array}{l}\text { Cross- } \\
\text { sectional, } \\
\text { population- } \\
\text { based }\end{array}$ & $\begin{array}{l}441 \\
\text { subjects, } \\
\text { aged } 65 \\
\text { years and } \\
\text { older }\end{array}$ & $\begin{array}{l}\text { Evaluation of } \\
\text { dietary intake }\end{array}$ & $\begin{array}{l}\text { MMSE, Geronte } \\
\text { scale for the } \\
\text { assessment of } \\
\text { daily living } \\
\text { activities }\end{array}$ & $\begin{array}{l}\text { In men, alcohol } \\
\text { intake was } \\
\text { associated with } \\
\text { improved } \\
\text { functional and } \\
\text { cognitive } \\
\text { parameters, while } \\
\text { PUFA intake only } \\
\text { with functional } \\
\text { status. In women, } \\
\text { lipid intakes were } \\
\text { related to better } \\
\text { cognitive } \\
\text { performance. } \\
\text { Overweight in both } \\
\text { sexes was } \\
\text { associated with an } \\
\text { improvement in } \\
\text { functional status. }\end{array}$ & $\begin{array}{l}\text { One of the first studies } \\
\text { on the possible role } \\
\text { of macronutrients in } \\
\text { ARCD. The } \\
\text { response rate of this } \\
\text { study was very low } \\
\text { (around } 50 \% \text { ) and } \\
\text { these findings, } \\
\text { contradictory to the } \\
\text { results of the } \\
\text { subsequent studies, } \\
\text { were explained by } \\
\text { the authors with the } \\
\text { fact that high intakes } \\
\text { of these dietary } \\
\text { factors can be } \\
\text { considered as an } \\
\text { indicator of a better } \\
\text { health status. }\end{array}$ \\
\hline $\begin{array}{l}\text { Ortega et } \\
\text { al.[19] }\end{array}$ & $\begin{array}{l}\text { Cross- } \\
\text { sectional }\end{array}$ & $\begin{array}{l}260 \\
\text { subjects, } \\
\text { aged 65- } \\
90 \text { years }\end{array}$ & $\begin{array}{l}\text { Evaluation of } \\
\text { dietary intake } \\
\text { with a } \\
\text { weighed-food } \\
\text { record for } 7 \\
\text { consecutive } \\
\text { days, and } \\
\text { biochemical } \\
\text { assays }\end{array}$ & MMSE, PMSQ & $\begin{array}{l}\text { A diet poor in } \\
\text { MUFA, SFA, and } \\
\text { cholesterol, but } \\
\text { rich in } \\
\text { carbohydrates, } \\
\text { fibers, vitamins } \\
\text { (folates, vitamins } \\
C \text { and } E \text {, and } \beta- \\
\text { carotene, and } \\
\text { minerals [zinc and } \\
\text { iron]) seems to } \\
\text { improve cognitive } \\
\text { skills. }\end{array}$ & $\begin{array}{l}\text { The apparently } \\
\text { conflicting findings } \\
\text { on MUFA intake and } \\
\text { cognitive function } \\
\text { between this study } \\
\text { and others could be } \\
\text { partially due to some } \\
\text { methodological } \\
\text { differences in FFQs } \\
\text { and selection of } \\
\text { participants. }\end{array}$ \\
\hline $\begin{array}{l}\text { Solfrizzi et } \\
\text { al.[20] }\end{array}$ & $\begin{array}{l}\text { Cross- } \\
\text { sectional, } \\
\text { population- } \\
\text { based }\end{array}$ & $\begin{array}{l}278 \\
\text { subjects, } \\
65-84 \\
\text { years old }\end{array}$ & $\begin{array}{l}\text { Evaluation of } \\
\text { dietary intake } \\
\text { with a 77- } \\
\text { item FFQ }\end{array}$ & $\begin{array}{l}\text { MMSE, DCT, and } \\
\text { BSRT }\end{array}$ & $\begin{array}{l}\text { Inverse relationship } \\
\text { between MUFA } \\
\text { intake and } \\
\text { cognitive decline. } \\
\text { Significant inverse } \\
\text { association } \\
\text { between MUFA } \\
\text { intakes and } \\
\text { selective attention. } \\
\text { No association } \\
\text { was found } \\
\text { between } \\
\text { nutritional } \\
\text { variables and } \\
\text { episodic memory. }\end{array}$ & $\begin{array}{l}\text { This study suggested } \\
\text { that high MUFA } \\
\text { intakes appeared to } \\
\text { be protective against } \\
\text { ARCD, with the } \\
\text { obvious limitations of } \\
\text { a cross-sectional } \\
\text { survey with a limited } \\
\text { number of subjects. }\end{array}$ \\
\hline
\end{tabular}


TABLE 1 (continued)

\begin{tabular}{|c|c|c|c|c|c|c|}
\hline Ref. & $\begin{array}{l}\text { Setting } \\
\text { and Study } \\
\text { Design }\end{array}$ & Subjects & $\begin{array}{c}\text { Dietary } \\
\text { Assessment }\end{array}$ & $\begin{array}{l}\text { Cognitive } \\
\text { Outcomes }\end{array}$ & $\begin{array}{l}\text { Results and } \\
\text { Conclusions }\end{array}$ & Comment \\
\hline $\begin{array}{l}\text { Manzato et } \\
\text { al.[21] }\end{array}$ & $\begin{array}{l}\text { Cross- } \\
\text { sectional, } \\
\text { population- } \\
\text { based }\end{array}$ & $\begin{array}{l}191 \\
\text { subjects, } \\
\text { aged } 65 \\
\text { years and } \\
\text { older }\end{array}$ & $\begin{array}{l}\text { Evaluation of } \\
\text { plasma } \\
\text { phospholipid } \\
\text { fatty acid } \\
\text { composition }\end{array}$ & $\begin{array}{l}\text { MMSE: subjects } \\
\text { with a score } \\
\text { between } 10 \text { and } \\
17 \text { vs. subjects } \\
\text { with a score } \\
\text { between } 28 \text { and } \\
30\end{array}$ & $\begin{array}{l}\text { Cognitive } \\
\text { functioning is } \\
\text { affected mainly by } \\
\text { age and } \\
\text { education, not by } \\
\text { dietary fatty acids. }\end{array}$ & $\begin{array}{l}\text { The authors } \\
\text { acknowledged that } \\
\text { these results were } \\
\text { limited by the fact } \\
\text { that total energy } \\
\text { intake, which is } \\
\text { known to be reduced } \\
\text { in patients with } \\
\text { cognitive impairment, } \\
\text { was not considered, } \\
\text { and by the fact that } \\
\text { the study was a } \\
\text { cross-sectional } \\
\text { survey. }\end{array}$ \\
\hline $\begin{array}{l}\text { Kalmijn et } \\
\text { al.[22] }\end{array}$ & $\begin{array}{l}\text { Cross- } \\
\text { sectional, } \\
\text { population- } \\
\text { based }\end{array}$ & $\begin{array}{l}1,613 \\
\text { subjects, } \\
45-70 \\
\text { years old }\end{array}$ & $\begin{array}{l}\text { Evaluation of } \\
\text { fatty fish, } \\
\text { total fat, } \\
\text { cholesterol, } \\
\text { SFA, MUFA, } \\
\text { PUFA (n-6 } \\
\text { and n-3) } \\
\text { dietary } \\
\text { intakes with a } \\
\text { 178-item } \\
\text { FFQ }\end{array}$ & $\begin{array}{l}\text { Concurrent to the } \\
\text { dietary } \\
\text { assessment, } \\
\text { the VVLT, the } \\
\text { CST, an } \\
\text { abbreviated } \\
\text { SCWT, the } \\
\text { LDST, a CFT } \\
\text { were } \\
\text { administered }\end{array}$ & $\begin{array}{l}\text { Fatty fish and } \\
\text { marine n-3 PUFA } \\
\text { consumption was } \\
\text { associated with a } \\
\text { reduced risk and } \\
\text { intake of } \\
\text { cholesterol, and } \\
\text { SFA with an } \\
\text { increased risk of } \\
\text { impaired cognitive } \\
\text { function in this } \\
\text { middle-aged } \\
\text { population. }\end{array}$ & $\begin{array}{l}\text { The association } \\
\text { between SFA and } \\
\text { cognitive function } \\
\text { appeared to be } \\
\text { independent of } \\
\text { differences in } \\
\text { cardiovascular risk } \\
\text { factors. }\end{array}$ \\
\hline $\begin{array}{l}\text { Nurk et } \\
\text { al.[35] }\end{array}$ & $\begin{array}{l}\text { Cross- } \\
\text { sectional, } \\
\text { population- } \\
\text { based }\end{array}$ & $\begin{array}{l}2,031 \\
\text { subjects, } \\
70-74 \\
\text { years old }\end{array}$ & $\begin{array}{l}\text { Evaluation of } \\
\text { dietary } \\
\text { intakes with a } \\
\text { 169-item } \\
\text { FFQ }\end{array}$ & $\begin{array}{l}\text { Six cognitive tests } \\
\text { were } \\
\text { administered: } \\
\text { m-MMSE, m- } \\
\text { DST, m-BD, } \\
\text { KOLT, TMT-A, } \\
\text { and the S-task } \\
\text { of the COWAT }\end{array}$ & $\begin{array}{l}\text { Consumers of fish } \\
\text { and fish products } \\
\text { had better } \\
\text { cognitive function } \\
\text { than did } \\
\text { nonconsumers. } \\
\text { The associations } \\
\text { between fish and } \\
\text { fish product intake } \\
\text { and cognition } \\
\text { were dose } \\
\text { dependent. The } \\
\text { effect of fish on } \\
\text { cognition differed } \\
\text { according to the } \\
\text { type of fish and } \\
\text { fish product } \\
\text { consumed. }\end{array}$ & $\begin{array}{l}\text { Although of cross- } \\
\text { sectional design, this } \\
\text { study had a large } \\
\text { population-based } \\
\text { sample with a } \\
\text { relatively high } \\
\text { consumption of fish } \\
\text { and fish products, } \\
\text { and with interesting } \\
\text { dose-response } \\
\text { analyses. }\end{array}$ \\
\hline
\end{tabular}


TABLE 1 (continued)

\begin{tabular}{|c|c|c|c|c|c|c|}
\hline Ref. & $\begin{array}{l}\text { Setting } \\
\text { and Study } \\
\text { Design }\end{array}$ & Subjects & $\begin{array}{c}\text { Dietary } \\
\text { Assessment }\end{array}$ & $\begin{array}{l}\text { Cognitive } \\
\text { Outcomes }\end{array}$ & $\begin{array}{l}\text { Results and } \\
\text { Conclusions }\end{array}$ & Comment \\
\hline $\begin{array}{l}\text { Dangour et } \\
\text { al.[32] }\end{array}$ & $\begin{array}{l}\text { Randomized } \\
\text { clinical trial } \\
(24 \\
\text { months })\end{array}$ & $\begin{array}{l}867 \\
\text { subjects, } \\
70-79 \\
\text { years old, } \\
\text { from } 20 \\
\text { general } \\
\text { practices } \\
\text { in England } \\
\text { and Wales }\end{array}$ & $\begin{array}{l}\text { Evaluation of } \\
\text { fish } \\
\text { consumption } \\
\text { variable that } \\
\text { took into } \\
\text { account both } \\
\text { frequency } \\
\text { and type of } \\
\text { fish } \\
\text { consumed }\end{array}$ & $\begin{array}{l}\text { A standardized } \\
\text { battery of } \\
\text { cognitive tests: } \\
\text { CVLT; } \\
\text { subjective } \\
\text { memory } \\
\text { assessment; } \\
\text { three tests of } \\
\text { prospective } \\
\text { memory; story } \\
\text { recall } \\
\text { (immediate and } \\
\text { delayed); verbal } \\
\text { fluency; letter } \\
\text { cancellation; } \\
\text { location } \\
\text { memory } \\
\text { (immediate and } \\
\text { delayed); } \\
\text { symbol-letter } \\
\text { substitution; } \\
\text { digit span } \\
\text { forwards and } \\
\text { backwards; } \\
\text { simple and } \\
\text { choice reaction } \\
\text { time }\end{array}$ & $\begin{array}{l}\text { High levels of fish } \\
\text { consumption are } \\
\text { associated with } \\
\text { better cognitive } \\
\text { function in later } \\
\text { life. }\end{array}$ & $\begin{array}{l}\text { Of particular interest, } \\
\text { although in a cross- } \\
\text { sectional study, there } \\
\text { was an apparent } \\
\text { linear trend for } \\
\text { increased cognitive } \\
\text { function across the } \\
\text { five-item fish } \\
\text { consumption } \\
\text { variable, with highest } \\
\text { cognitive function } \\
\text { levels found in those } \\
\text { individuals who } \\
\text { report eating the } \\
\text { largest amount of } \\
\text { fatty, as opposed to } \\
\text { white. fish. }\end{array}$ \\
\hline \multicolumn{7}{|c|}{ Longitudinal studies } \\
\hline $\begin{array}{l}\text { Kalmijn et } \\
\text { al.[24] }\end{array}$ & $\begin{array}{l}\text { Longitudinal, } \\
\text { population- } \\
\text { based ( } 3 \\
\text { years) }\end{array}$ & $\begin{array}{l}476 \\
\text { subjects, } \\
\text { aged 69- } \\
89 \text { years }\end{array}$ & $\begin{array}{l}\text { Evaluation of } \\
\text { dietary intake } \\
\text { with the } \\
\text { cross-check } \\
\text { dietary } \\
\text { history } \\
\text { method }\end{array}$ & $\begin{array}{l}\text { Cognitive } \\
\text { impairment } \\
\text { defined as a } \\
\text { MMSE score } \\
<25 \text { points and } \\
\text { cognitive } \\
\text { decline as a } \\
\text { drop of }>2 \\
\text { points of MMSE } \\
\text { over a 3-year } \\
\text { period }\end{array}$ & $\begin{array}{l}\text { High linoleic acid } \\
\text { intake (PUFA) was } \\
\text { positively } \\
\text { associated with } \\
\text { cognitive } \\
\text { impairment. High } \\
\text { fish consumption } \\
\text { was inversely } \\
\text { associated with } \\
\text { cognitive } \\
\text { impairment. }\end{array}$ & $\begin{array}{l}\text { The first longitudinal } \\
\text { study on the possible } \\
\text { role of dietary fatty } \\
\text { acids and fish } \\
\text { consumption on } \\
\text { ARCD. }\end{array}$ \\
\hline $\begin{array}{l}\text { Hende et } \\
\text { al.[25] }\end{array}$ & $\begin{array}{l}\text { Longitudinal, } \\
\text { population- } \\
\text { based (4 } \\
\text { years) }\end{array}$ & $\begin{array}{l}246 \\
\text { subjects, } \\
\text { aged } 63- \\
74 \text { years }\end{array}$ & $\begin{array}{l}\text { Evaluation of } \\
\text { fatty acid } \\
\text { composition } \\
\text { in erythrocyte } \\
\text { membranes }\end{array}$ & $\begin{array}{l}\text { MMSE score with } \\
\text { a >2-point } \\
\text { decrease in a 4- } \\
\text { year follow-up }\end{array}$ & $\begin{array}{l}\text { Inverse association } \\
\text { between cognitive } \\
\text { decline and the } \\
\text { ratio of } n-3 \text { to } n-6 \\
\text { PUFA in } \\
\text { erythrocyte } \\
\text { membranes }\end{array}$ & $\begin{array}{l}\text { This is the first report } \\
\text { relating the fatty acid } \\
\text { composition of } \\
\text { erythrocyte } \\
\text { membranes to } \\
\text { cognitive decline in } \\
\text { the elderly. No } \\
\text { dietary intake data } \\
\text { were collected in this } \\
\text { study, but the } \\
\text { erythrocyte } \\
\text { membrane fatty acid } \\
\text { composition can } \\
\text { reflect dietary fat } \\
\text { intake. }\end{array}$ \\
\hline
\end{tabular}


TABLE 1 (continued)

\begin{tabular}{|c|c|c|c|c|c|c|}
\hline Ref. & $\begin{array}{l}\text { Setting } \\
\text { and Study } \\
\text { Design }\end{array}$ & Subjects & $\begin{array}{c}\text { Dietary } \\
\text { Assessment }\end{array}$ & $\begin{array}{l}\text { Cognitive } \\
\text { Outcomes }\end{array}$ & $\begin{array}{l}\text { Results and } \\
\text { Conclusions }\end{array}$ & Comment \\
\hline $\begin{array}{l}\text { Morris et } \\
\text { al.[26] }\end{array}$ & $\begin{array}{l}\text { Longitudinal, } \\
\text { population- } \\
\text { based ( } 6 \\
\text { years) }\end{array}$ & $\begin{array}{l}2,560 \\
\text { subjects, } \\
\text { aged } 65 \\
\text { years and } \\
\text { older }\end{array}$ & $\begin{array}{l}\text { Evaluation of } \\
\text { dietary intake } \\
\text { with a 139- } \\
\text { item FFQ }\end{array}$ & $\begin{array}{l}\text { Cognitive change } \\
\text { at } 3 \text { - and 6-year } \\
\text { follow-ups } \\
\text { measured with } \\
\text { the EBT of } \\
\text { Immediate and } \\
\text { Delayed Recall, } \\
\text { the MMSE, and } \\
\text { the SDMT }\end{array}$ & $\begin{array}{l}\text { A diet high in } \\
\text { saturated and } \\
\text { trans-unsaturated } \\
\text { fat, or low in } \\
\text { nonhydrogenated } \\
\text { unsaturated fats } \\
\text { may be associated } \\
\text { with cognitive } \\
\text { decline among } \\
\text { older people. }\end{array}$ & $\begin{array}{l}\text { The first longitudinal } \\
\text { study in which higher } \\
\text { SFA intake was } \\
\text { associated with } \\
\text { cognitive decline, } \\
\text { and higher MUFA } \\
\text { intake and } \\
\text { PUFA/SFA protected } \\
\text { against ARCD. }\end{array}$ \\
\hline $\begin{array}{l}\text { Morris et } \\
\text { al.[33] }\end{array}$ & $\begin{array}{l}\text { Longitudinal, } \\
\text { population- } \\
\text { based ( } 6 \\
\text { years) }\end{array}$ & $\begin{array}{l}3,718 \\
\text { subjects, } \\
\text { aged } 65 \\
\text { years and } \\
\text { older }\end{array}$ & $\begin{array}{l}\text { Evaluation of } \\
\text { dietary intake } \\
\text { with a 139- } \\
\text { item FFQ }\end{array}$ & $\begin{array}{l}\text { Cognitive change } \\
\text { at 3-and 6-year } \\
\text { follow-ups } \\
\text { measured with } \\
\text { the EBT of } \\
\text { Immediate and } \\
\text { Delayed Recall, } \\
\text { the MMSE, and } \\
\text { the SDMT }\end{array}$ & $\begin{array}{l}\text { Dietary intake of fish } \\
\text { was inversely } \\
\text { associated with } \\
\text { cognitive decline } \\
\text { over } 6 \text { years. } \\
\text { There were no } \\
\text { consistent } \\
\text { associations with } \\
\text { the n-3 fatty acids, } \\
\text { although the effect } \\
\text { estimates were in } \\
\text { the direction of } \\
\text { slower decline. }\end{array}$ & $\begin{array}{l}\text { Longitudinal study } \\
\text { confirming the } \\
\text { protection of fish } \\
\text { consumption, but not } \\
\text { of higher intake of n- } \\
3 \text { PUFA against } \\
\text { ARCD. }\end{array}$ \\
\hline $\begin{array}{l}\text { Morris et } \\
\text { al.[27] }\end{array}$ & $\begin{array}{l}\text { Longitudinal, } \\
\text { population- } \\
\text { based ( } 6 \\
\text { years) }\end{array}$ & $\begin{array}{l}3,718 \\
\text { subjects, } \\
\text { aged } 65 \\
\text { years and } \\
\text { older }\end{array}$ & $\begin{array}{l}\text { Evaluation of } \\
\text { dietary intake } \\
\text { with a 139- } \\
\text { item FFQ }\end{array}$ & $\begin{array}{l}\text { Cognitive change } \\
\text { at 3-and 6-year } \\
\text { follow-ups } \\
\text { measured with } \\
\text { the EBT of } \\
\text { Immediate and } \\
\text { Delayed Recall, } \\
\text { the MMSE, and } \\
\text { the SDMT }\end{array}$ & $\begin{array}{l}\text { High copper intake } \\
\text { was associated } \\
\text { with a significantly } \\
\text { faster rate of } \\
\text { cognitive decline, } \\
\text { but only among } \\
\text { persons who also } \\
\text { consumed a diet } \\
\text { that was high in } \\
\text { saturated and } \\
\text { trans fats. }\end{array}$ & $\begin{array}{l}\text { Study suggesting an } \\
\text { accelerated cognitive } \\
\text { decline among } \\
\text { persons whose diets } \\
\text { were high in copper } \\
\text { and saturated and } \\
\text { trans fats, confirming } \\
\text { some suggestions of } \\
\text { previous case-control } \\
\text { studies with elevated } \\
\text { serum copper in AD } \\
\text { patients. }\end{array}$ \\
\hline $\begin{array}{l}\text { Solfrizzi et } \\
\text { al.[30] }\end{array}$ & $\begin{array}{l}\text { Longitudinal, } \\
\text { population- } \\
\text { based ( } 8.5 \\
\text { years) }\end{array}$ & $\begin{array}{l}278 \\
\text { subjects, } \\
65-84 \\
\text { years old, } \\
\text { from a } \\
\text { cohort of } \\
5,632 \\
\text { subjects }\end{array}$ & $\begin{array}{l}\text { Evaluation of } \\
\text { MUFA and } \\
\text { PUFA dietary } \\
\text { intakes with a } \\
\text { 77-item FFQ }\end{array}$ & MMSE & $\begin{array}{l}\text { High MUFA, PUFA, } \\
\text { and total energy } \\
\text { intake were } \\
\text { significantly } \\
\text { associated with a } \\
\text { better cognitive } \\
\text { performance in } \\
\text { time. The } \\
\text { association } \\
\text { between high } \\
\text { MUFA and PUFA } \\
\text { intakes and } \\
\text { cognitive } \\
\text { performance } \\
\text { remained robust } \\
\text { even after } \\
\text { adjustment for } \\
\text { potential } \\
\text { confounding } \\
\text { variables, such as } \\
\text { age, sex, } \\
\text { educational level, } \\
\text { CCI, BMI, and } \\
\text { total energy } \\
\text { intakes. }\end{array}$ & $\begin{array}{l}\text { Longitudinal } \\
\text { confirmatory study } \\
\text { on the protective role } \\
\text { of MUFA and PUFA } \\
\text { against ARCD with a } \\
\text { longer follow-up } \\
\text { period. }\end{array}$ \\
\hline
\end{tabular}


TABLE 1 (continued)

\begin{tabular}{|c|c|c|c|c|c|c|}
\hline Ref. & $\begin{array}{l}\text { Setting } \\
\text { and Study } \\
\text { Design }\end{array}$ & Subjects & $\begin{array}{c}\text { Dietary } \\
\text { Assessment }\end{array}$ & $\begin{array}{l}\text { Cognitive } \\
\text { Outcomes }\end{array}$ & $\begin{array}{l}\text { Results and } \\
\text { Conclusions }\end{array}$ & Comment \\
\hline $\begin{array}{l}\text { Solfrizzi et } \\
\text { al.[31] }\end{array}$ & $\begin{array}{l}\text { Longitudinal, } \\
\text { population- } \\
\text { based ( } 2.6 \\
\text { years) }\end{array}$ & $\begin{array}{l}278 \\
\quad \text { subjects, } \\
65-84 \\
\text { years old, } \\
\text { from a } \\
\text { cohort of } \\
5,632 \\
\text { subjects }\end{array}$ & $\begin{array}{l}\text { Evaluation of } \\
\text { MUFA and } \\
\text { PUFA dietary } \\
\text { intakes with a } \\
\text { 77-item FFQ }\end{array}$ & $\begin{array}{l}\text { Incident } \mathrm{MCl} \text {. } \\
\text { Diagnostic } \\
\text { criteria for } \mathrm{MCl} \text { : } \\
\text { 1.5 S.D. below } \\
\text { mean age- and } \\
\text { education- } \\
\text { adjusted on the } \\
\text { MMSE and 10th } \\
\text { percentile } \\
\text { below age- and } \\
\text { education- } \\
\text { adjusted on } \\
\text { memory test, } \\
\text { without SMC } \\
\text { and intact } \\
\text { ADL/IADL }\end{array}$ & $\begin{array}{l}\text { Dietary fatty acid } \\
\text { intakes were not } \\
\text { associated with } \\
\text { incident } \mathrm{MCl} \text {. } \\
\text { However, high } \\
\text { PUFA intake } \\
\text { appeared to have } \\
\text { a borderline } \\
\text { nonsignificant } \\
\text { trend for a } \\
\text { protective effect } \\
\text { against the } \\
\text { development of } \\
\text { MCl that may be } \\
\text { important. }\end{array}$ & $\begin{array}{l}\text { In this population- } \\
\text { based study, dietary } \\
\text { fatty acid intakes } \\
\text { were associated for } \\
\text { the first time with } \\
\text { incident } \mathrm{MCl} \text {, } \\
\text { although in a limited } \\
\text { sample with a brief } \\
\text { follow-up period. }\end{array}$ \\
\hline $\begin{array}{l}\text { van Gelder } \\
\text { et al.[34] }\end{array}$ & $\begin{array}{l}\text { Longitudinal, } \\
\text { population- } \\
\text { based ( } 5 \\
\text { years) }\end{array}$ & $\begin{array}{l}210 \\
\text { subjects, } \\
70-89 \\
\text { years old }\end{array}$ & $\begin{array}{l}\text { Information } \\
\text { about } \\
\text { habitual food } \\
\text { consumption } \\
\text { was collected } \\
\text { using the } \\
\text { cross-check } \\
\text { dietary } \\
\text { history } \\
\text { method }\end{array}$ & MMSE & $\begin{array}{l}\text { Fish consumption } \\
\text { was associated } \\
\text { with less } \\
\text { subsequent 5-year } \\
\text { cognitive decline } \\
\text { than no fish } \\
\text { consumption. } \\
\text { Furthermore, a } \\
\text { dose-response } \\
\text { relation was noted } \\
\text { between the } \\
\text { combined intake } \\
\text { of EPA and DHA } \\
\text { and cognitive } \\
\text { decline, which } \\
\text { suggests that a } \\
\text { higher intake of } \\
\text { EPA plus DHA } \\
\text { was associated } \\
\text { with less cognitive } \\
\text { decline. }\end{array}$ & $\begin{array}{l}\text { Possible explanations } \\
\text { for the discrepancy } \\
\text { between the earlier } \\
\text { results of the } \\
\text { Zutphen Elderly } \\
\text { Study[24] and these } \\
\text { findings could be the } \\
\text { longer follow-up } \\
\text { period and the } \\
\text { availability of data on } \\
\text { the EPA and DHA } \\
\text { content of animal } \\
\text { and plant foods in } \\
\text { addition to fish and } \\
\text { seafood. }\end{array}$ \\
\hline $\begin{array}{l}\text { Psaltopoulou } \\
\text { et al.[28] }\end{array}$ & $\begin{array}{l}\text { Longitudinal, } \\
\text { population- } \\
\text { based } \\
\text { (median } 8 \\
\text { years) }\end{array}$ & $\begin{array}{l}732 \\
\text { subjects, } \\
60 \text { years } \\
\text { or older }\end{array}$ & $\begin{array}{l}\text { Evaluation of } \\
\text { dietary } \\
\text { intakes with a } \\
\text { 150-item } \\
\text { FFQ. A } \\
\text { dietary } \\
\text { composite } \\
\text { score (MeDi } \\
\text { score) } \\
\text { evaluated } \\
\text { adherence to } \\
\text { Medi- } \\
\text { terranean } \\
\text { diet. }\end{array}$ & MMSE & $\begin{array}{l}\text { No significant } \\
\text { association } \\
\text { between MeDi } \\
\text { score and MMSE } \\
\text { scores, whereas a } \\
\text { statistically } \\
\text { significant inverse } \\
\text { association was } \\
\text { found between } \\
\text { MMSE } \\
\text { performance and } \\
\text { some individual } \\
\text { dietary } \\
\text { components, such } \\
\text { as seed oil or } \\
\text { PUFA intakes. }\end{array}$ & $\begin{array}{l}\text { Although a longer } \\
\text { median follow-up } \\
\text { period, the lack of } \\
\text { cognitive } \\
\text { assessment at } \\
\text { baseline did not } \\
\text { allow the estimation } \\
\text { of patterns of } \\
\text { decline, and to } \\
\text { document } \\
\text { conclusively the } \\
\text { causal nature and } \\
\text { the directionality of } \\
\text { associations. }\end{array}$ \\
\hline
\end{tabular}


TABLE 1 (continued)

\begin{tabular}{|c|c|c|c|c|c|c|}
\hline Ref. & $\begin{array}{l}\text { Setting } \\
\text { and Study } \\
\text { Design }\end{array}$ & Subjects & $\begin{array}{c}\text { Dietary } \\
\text { Assessment }\end{array}$ & $\begin{array}{l}\text { Cognitive } \\
\text { Outcomes }\end{array}$ & $\begin{array}{l}\text { Results and } \\
\text { Conclusions }\end{array}$ & Comment \\
\hline $\begin{array}{r}\text { Vercambre } \\
\text { et al.[29] }\end{array}$ & $\begin{array}{l}\text { Longitudinal, } \\
\text { population- } \\
\text { based (13 } \\
\text { years) }\end{array}$ & $\begin{array}{l}\text { 4,809 elderly } \\
\text { women, } \\
76-82 \\
\text { years old }\end{array}$ & $\begin{array}{l}\text { Evaluation of } \\
\text { dietary } \\
\text { intakes with a } \\
\text { 208-item } \\
\text { FFQ }\end{array}$ & DECO and IADL & $\begin{array}{l}\text { Elderly women that } \\
\text { were reported by } \\
\text { informants to have } \\
\text { undergone recent } \\
\text { cognitive decline } \\
\text { had, } 13 \text { years } \\
\text { previously, lower } \\
\text { intakes of poultry, } \\
\text { fish, and animal } \\
\text { fats, as well as } \\
\text { higher intakes of } \\
\text { dairy desserts and } \\
\text { ice cream. They } \\
\text { had lower habitual } \\
\text { intakes of dietary } \\
\text { fiber and n-3 } \\
\text { PUFA, but a } \\
\text { higher intake of } \\
\text { retinol. } \\
\text { Furthermore, } \\
\text { elderly women } \\
\text { that were reported } \\
\text { by informants to } \\
\text { be functionally } \\
\text { impaired had, in } \\
\text { the past, lower } \\
\text { intakes of } \\
\text { vegetables and } \\
\text { vitamins B2, B6, } \\
\text { and B12. }\end{array}$ & $\begin{array}{l}\text { The main interest of } \\
\text { this study lay in the } \\
\text { time interval (more } \\
\text { than a decade) } \\
\text { between dietary } \\
\text { assessment and } \\
\text { cognitive and } \\
\text { functional } \\
\text { assessment, } \\
\text { although in a sample } \\
\text { of only women, so } \\
\text { limiting the } \\
\text { generalizability of the } \\
\text { findings. }\end{array}$ \\
\hline
\end{tabular}

$\mathrm{ADL}=$ activities of daily living; $\mathrm{BMI}=$ body mass index; BSRT = Babcock Recall Story Test (episodic memory); CCl = Charlson Comorbidity Index; CFT = Category Fluency Test (semantic memory); CST = Concept Shifting Task (mental processing speed); CVLT = Californian Verbal Learning Test (verbal memory); DCT = Digit Cancellation Test (selective attention); DECO = DEtérioration Cognitive Observéè scale (observed cognitive deterioration); DHA = docosahexaenoic acid; EBT = East Boston Memory test (immediate and delayed episodic memory); EPA = eicosapentaenoic acid; $F F Q=$ food frequency questionnaire; $I A D L=$ instrumental activities of daily living; KOLT = Kendrick Object Learning Test (episodic memory); LDST = Letter Digit Substitution Test (perceptual-motor speed); $\mathrm{m}-\mathrm{BD}=$ modified Block Design (visuospatial and motor skills); $\mathrm{m}$-DST = modified Digit Symbol Test (perceptual speed); $\mathrm{m}-\mathrm{MMSE}=$ modified Mini-Mental State Examination (global cognitive functioning); MMSE = Mini-Mental State Examination (global cognitive functioning); PMSQ = Pfeiffer's Mental State Questionnaire (global cognitive functioning); SCWT = Stroop Color Word Test (selective attention); SDMT = Symbol Digit Modalities Test (perceptual-motor speed); SMC $=$ Subjective Memory Complaint; S-task of the COWAT $=$ the abridged version of the Controlled Oral Word Association Test (access to semantic memory); TMT-A = Trail Making Test, part A (executive function); VVLT = Visual Verbal Learning Test (verbal memory).

\section{REFERENCES}

1. $\quad$ Aisen, P.S. (2008) Treatment for MCI: is the evidence sufficient? Neurology 70, 2020-2021.

2. Panza, F., D'Introno, A., Colacicco, A.M., Capurso, C., Del Parigi, A., Caselli, R.J., Pilotto, A., Argentieri, G., Scapicchio, P.L., Scafato, E., Capurso, A., and Solfrizzi, V. (2005) Current epidemiology of mild cognitive impairment and other predementia syndromes. Am. J. Geriatr. Psychiatry 13, 633-644.

3. Panza, F., D'Introno, A., Colacicco, A.M., Capurso, C., Del Parigi, A., Capurso, S.A., Caselli, R.J., Pilotto, A., Scafato, E., Capurso, A., and Solfrizzi, V. (2006) Cognitive frailty: predementia syndrome and vascular risk factors. Neurobiol. Aging 27, 933-940.

4. Flicker, C., Ferris, S.H., and Reisberg, B. (1991) Mild cognitive impairment in the elderly: predictors of dementia. Neurology 41, 1006-1009.

5. Petersen, R.C., Smith, G.E., Waring, S.C., Ivnik, R.J., Tangalos, E.G., and Kokmen, E. (1999) Mild cognitive impairment: clinical characterization and outcome. Arch. Neurol. 56, 303-308. 
6. Petersen, R.C., Doody, R., Kurz, A., Mohs, R.C., Morris, J.C., Rabins, P.V., Ritchie, K., Rossor, M., Thal, L., and Winblad, B. (2001) Current concepts in mild cognitive decline. Arch. Neurol. 58, 1985-1892.

7. Winblad, B., Palmer, K., Kivipelto, M., Jelic, V., Fratiglioni, L., Wahlund, L.O., Nordberg, A., Backman, L., Albert, M., Almkvist, O., Arai, H., Basun, H., Blennow, K., de Leon, M., DeCarli, C., Erkinjuntti, T., Giacobini, E., Graff, C., Hardy, J., Jack, C., Jorm, A., Ritchie, K., van Duijn, C., Visser, P., and Petersen, R.C. (2004) Mild cognitive impairment--beyond controversies, towards a consensus: report of the International Working Group on Mild Cognitive Impairment. J. Intern. Med. 256, 240-246.

8. Luis, C.A., Loewenstein, D.A., Acevedo, A., Barker, W.W., and Duara, R. (2003) Mild cognitive impairment: directions for future research. Neurology 61, 438-444.

9. Gauthier, S., Reisberg, B., and Zaudig, M. (2006) International Psychogeriatric Association Expert Conference on mild cognitive impairment. Mild cognitive impairment. Lancet 367, 1262-1270.

10. Portet, F., Ousset, P.J., Visser, P.J., Frisoni, G.B., Nobili, F., Scheltens, P., Vellas, B., Touchon, J.; MCI Working Group of the European Consortium on Alzheimer's Disease (EADC) (2006) Mild cognitive impairment (MCI) in medical practice: a critical review of the concept and new diagnostic procedure. Report of the MCI Working Group of the European Consortium on Alzheimer's Disease. J. Neurol. Neurosurg. Psychiatry 77, 714-718.

11. American Psychiatric Association Committee on Nomenclature and Statistics (1994) Diagnostic and Statistical Manual of Mental Disorders. American Psychiatric Association, Washington, D.C.

12. Levy, R. (1994) Aging-associated cognitive decline. Working Party of the International Psychogeriatric Association in collaboration with the World Health Organization. Int. Psychogeriatr. 6, 63-68.

13. Solfrizzi, V., Capurso, C., D'Introno, A., Colacicco, A.M., Santamato, A., Ranieri, M., Fiore, P., Capurso, A., and Panza, F. (2008) Lifestyle-related factors in predementia and dementia syndromes. Expert Rev. Neurother. 8, 133158.

14. Solfrizzi, V., Colacicco, A.M., D'Introno, A., Capurso, C., Parigi, A.D., Capurso, S.A., Torres, F., Capurso, A., and Panza, F. (2006) Macronutrients; aluminium from drinking water and foods; and other metals in cognitive decline and dementia. J. Alzheimers Dis. 10, 303-330.

15. Panza, F., D'Introno, A., Colacicco, A.M., Basile, A.M., Capurso, C., Kehoe, P.G., Capurso, A., and Solfrizzi, V. (2004) Vascular risk and genetics of sporadic late-onset Alzheimer's disease. J. Neural Transm. 111, 69-89.

16. Solfrizzi, V., D'Introno, A., Colacicco, A.M., Capurso, C., Del Parigi, A., Capurso, S., Gadaleta, A., Capurso, A., and Panza, F. (2005) Dietary fatty acids intake: possible role in cognitive decline and dementia. Exp. Gerontol. 40, 257270.

17. Panza, F., Solfrizzi, V., Colacicco, A.M., D'Introno, A., Capurso, C., Torres, F., Del Parigi, A., Capurso, S., and Capurso, A. (2004) Mediterranean diet and cognitive decline. Public Health Nutr. 7, 959-963.

18. Pradignac, A., Schlienger, J.L., Velten, M., and Mejean, L. (1995) Relationships between macronutrient intake, handicaps, and cognitive impairments in free living elderly people. Aging Clin. Exp. Res. 7, 67-74.

19. Ortega, R.M., Requejo, A.M., Andres, P., Lopez-Sobaler, AM., Quintas, M.E., Redondo, M.R., Navia, B., and Rivas, T. (1997) Dietary intake and cognitive function in a group of elderly people. Am. J. Clin. Nutr. 66, 803-809.

20. Solfrizzi, V., Panza, F., Torres, F., Mastroianni, F., Del Parigi, A., Venezia, A., and Capurso, A. (1999) High monounsaturated fatty acids intake protects against age-related cognitive decline. Neurology 52, 1563-1569.

21. Manzato, E., Roselli della Rovere, G., Zambon, S., Romanato, G., Corti, M.C., Sartori, L., Baggio, G., and Crepaldi, G. (2003) Cognitive functions are not affected by dietary fatty acids in elderly in the Pro.V.A. study population. Aging Clin. Exp. Res. 15, 83-86.

22. Kalmijn, S., van Boxtel, M.P., Ocke, M., Verschuren, W.M., Kromhout, D., and Launer, L.J. (2004) Dietary intake of fatty acids and fish in relation to cognitive performance at middle age. Neurology 62, 275-280.

23. Conquer, J.A., Tierney, M.C., Zecevic, J., Bettger, W.J., and Fisher, R.H.(2000) Fatty acid analysis of blood plasma of patients with Alzheimer disease, other types of dementia, and cognitive impairment. Lipids 35, 1305-1312.

24. Kalmijn, S., Feskens, E.J., Launer, L.J., and Kromhout, D. (1997) Polyunsaturated fatty acids, antioxidants, and cognitive functions in very old men. Am. J. Epidemiol. 145, 33-41.

25. Hende, B., Ducimitiere, P., and Berr, C. (2003) Cognitive decline and fatty acid composition of erythrocyte membranes - The EVA Study. Am. J. Clin. Nutr. 77, 803-808.

26. Morris, M.C., Evans, D.A., Bienias, J.L., Tangney, C.C., Bennett, D.A., and Wilson, R.S. (2004) Dietary fat intake and 6-year cognitive change in an older biracial community population. Neurology 62, 1573-1579.

27. Morris, M.C., Evans, D.A., Tangney, C.C., Bienias, J.L., Schneider, J.A., Wilson, R.S., and Scherr, P.A. (2005) Dietary copper and high saturated and trans fat intakes associated with cognitive decline. Arch. Neurol. 63, 10851088.

28. Psaltopoulou, T., Kyrozis, A., Stathopoulos, P., Trichopoulos, D., Vassilopoulos, D., and Trichopoulou, A. (2008) Diet; physical activity and cognitive impairment among elders: the EPIC-Greece cohort (European Prospective Investigation into Cancer and Nutrition). Public Health Nutr. 11(10), 1054-1062.

29. Vercambre, M.N., Boutron-Ruault, M.C., Ritchie, K., Clavel-Chapelon, F., and Berr, C. (2009) Long-term association of food and nutrient intakes with cognitive and functional decline: a 13-year follow-up study of elderly French women. Br. J. Nutr. \{Epub ahead of print] 
30. Solfrizzi, V., Colacicco, A.M., D'Introno, A., Capurso, C., Torres, F., Rizzo, C., Capurso, A., and Panza, F (2006) Dietary intake of unsaturated fatty acids and age-related cognitive decline: a 8.5-year follow-up of the Italian Longitudinal Study on Aging. Neurobiol. Aging 27, 1694-1704.

31. Solfrizzi, V., Colacicco, A.M., D'Introno, A., Capurso, C., Del Parigi, A., Capurso, S.A., Argentieri, G., Capurso, A., and Panza, F. (2006) Dietary polyunsaturated fatty acids intakes and rate of mild cognitive impairment. The Italian Longitudinal Study on Aging. Exp. Gerontol. 41, 619-627.

32. Dangour, A.D., Allen, E., Elbourne, D., Fletcher, A., Richards, M., and Uauy, R. (2009) Fish consumption and cognitive function among older people in the UK: baseline data from the Opal Study. J. Nutr. Health Aging 13, 198202.

33. Morris, M.C., Evans, D.A., Tangney, C.C., Bienias, J.L., and Wilson, R.S. (2005) Fish consumption and cognitive decline with age in a large community study. Arch. Neurol. 62, 1849-1853.

34. van Gelder, B.M., Tijhuis, M., Kalmijn, S., and Kromhout, D. (2007) Fish consumption, n-3 fatty acids, and subsequent 5-y cognitive decline in elderly men: the Zutphen Elderly Study. Am. J. Clin. Nutr. 85, 1142-1147.

Nurk, E., Drevon, C.A., Refsum, H., Solvoll, K., Vollset, S.E., Nygård, O., Nygaard, H.A., Engedal, K., Tell, G.S., and Smith, D.A. (2007) Cognitive performance among the elderly and dietary fish intake: the Hordaland Health Study. Am. J. Clin. Nutr. 86, 1470-1478.

36. Engelhart, M.J., Geerlings, M.I., Ruitenberg, A., Van Swieten, J.C., Hofman, A., Witteman, J.C., et al. (2002) Diet and risk of dementia: does fat matter?: The Rotterdam Study. Neurology 59, 1915-1921.

37. Yehuda, S., Rabinovtz, S., Carasso, R.L., and Mostofsky, D.I. (1996) Essential fatty acids preparation (SR-3) improves Alzheimer's patients quality of life. Int. J. Neurosci. 87, 141-149.

38. Terano, T., Fujishiro, S., Ban, T., Yamamoto, K., Tanaka, T., Noguchi, Y., Tamura, Y., Yazawa, K., and Hirayama, T. (1999) Docosahexaenoic acid supplementation improves the moderately severe dementia from thrombotic cerebrovascular diseases. Lipids 34(Suppl), S345-S346.

39. Freund-Levi, Y., Eriksdotter-Jönhagen, M., Cederholm, T., Basun, H., Faxén-Irving, G., Garlind, A., Vedin, I., Vessby, B., Wahlund, L.O., and Palmblad, J. (2006) $\omega-3$ Fatty acid treatment in 174 patients with mild to moderate Alzheimer disease: OmegAD Study: a randomized double-blind trial. Arch. Neurol. 63, 1402-1408.

40. Freund-Levi, Y., Basun, H., Cederholm, T., Faxén-Irving, G., Garlind, A., Grut, M., Vedin, I., Palmblad, J., Wahlund, L.O., and Eriksdotter-Jönhagen, M. (2008) Omega-3 supplementation in mild to moderate Alzheimer's disease: effects on neuropsychiatric symptoms. Int. J. Geriatr. Psychiatry 23, 161-169.

41. Kotani, S., Sakaguchi, E., Warashina, S., Matsukawa, N., Ishikura, Y., Kiso, Y., Sakakibara, M., Yoshimoto, T., Guo, J., and Yamashima, T. (2006) Dietary supplementation of arachidonic and docosahexaenoic acids improves cognitive dysfunction. Neurosci. Res. 56, 159-164.

42. Chiu, C.C., Su, K.P., Cheng, T.C., Liu, H.C., Chang, C.J., Dewey, M.E., Stewart, R., and Huang, S.Y. (2008) The effects of omega-3 fatty acids monotherapy in Alzheimer's disease and mild cognitive impairment: a preliminary randomized double-blind placebo-controlled study. Prog. Neuropsychopharmacol. Biol. Psychiatry 32, 1538-1544.

43. Lim, W.S., Gammack, J.K., Van Niekerk, J.K., and Dangour, A. (2006) Omega 3 fatty acid for the prevention of dementia. Cochrane Database Syst. Rev. CD005379.

44. van de Rest, O., Geleijnse, J.M., Kok, F.J., van Staveren, W.A., Hoefnagels, W.H., Beekman, A.T., and de Groot, L.C. (2008) Effect of fish-oil supplementation on mental well-being in older subjects: a randomized, double-blind, placebo-controlled trial. Am. J. Clin. Nutr. 88, 706-713.

45. van de Rest, O., Geleijnse, J.M., Kok, F.J., van Staveren, W.A., Dullemeijer, C., Olderikkert, M.G., Beekman, A.T., and de Groot, C.P. (2008) Effect of fish oil on cognitive performance in older subjects: a randomized, controlled trial. Neurology 71, 430-438.

46. Dangour, A.D., Clemens, F., Elbourne, D., Fasey, N., Fletcher, A.E., Hardy, P., Holder, G.E., Huppert, F.A., Knight, R., Letley, L., Richards, M., Truesdale, A., Vickers, M., and Uauy, R. (2006) A randomised controlled trial investigating the effect of n-3 long-chain polyunsaturated fatty acid supplementation on cognitive and retinal function in cognitively healthy older people: the Older People And n-3 Long-chain polyunsaturated fatty acids (OPAL) study protocol[ISRCTN72331636]. Nutr. J. 5, 20.

47. Panza, F., Capurso, C., D'Introno, A., Colacicco, A.M., Chirico, M., Capurso, A., and Solfrizzi, V. (2007) Dietary polyunsaturated fatty acid supplementation; pre-dementia syndromes; and Alzheimer's disease. J. Am. Geriatr. Soc. 55, 469-470.

48. Hooijmans, C.R. and Kiliaan, A.J. (2008) Fatty acids, lipid metabolism and Alzheimer pathology. Eur. J. Pharmacol. 585, 176-196

49. Florent-Béchard, S., Malaplate-Armand, C., Koziel, V., Kriem, B., Olivier, J.-L., Pillot, T., and Oster, T. (2007) Towards a nutritional approach for prevention of Alzheimer's disease: biochemical and cellular aspects. J. Neurol. Sci. 262, 27-36.

50. Joseph, J.A., Shukitt-Hale, B., Denisova, N.A., Bielinski, D., Martin, A., McEwen, J.J., and Bickford, P.C. (1999) Reversals of age-related declines in neuronal signal transduction, cognitive, and motor behavioral deficits with blueberry, spinach, or strawberry dietary supplementation. J. Neurosci. 19, 8114-8121.

51. Moriguchi, T., Greiner, R.S., and Salem, N. (2000) Behavioral deficits associated with dietary induction of decreased brain docosahexaenoic acid concentration. J. Neurochem. 75, 2563-2573. 
52. Hashimoto, M., Tanabe, Y., Fujii, Y., Kikuta, T., Shibata, H., and Shido, O. (2005) Chronic administration of docosahexaenoic acid ameliorates the impairment of spatial cognition learning ability in amyloid \{beta\}-infused rats. J. Nutr. 135, 549-555.

53. Hashimoto, M., Hossain, S., Shimada, T., Sugioka, K., Yamasaki, H., Fujii, Y., Ishibashi, Y., Oka, J., and Shido, O. (2002) Docosahexaenoic acid provides protection from impairment of learning ability in Alzheimer's disease model rats. J. Neurochem. 81, 1084-1091.

54. Lim, G.P., Calon, F., Morihara, T., Yang, F., Teter, B., Ubeda, O., Salem, N., Jr., Frautschy, S.A., and Cole, G.M. (2005) A diet enriched with the omega-3 fatty acid docosahexaenoic acid reduces amyloid burden in an aged Alzheimer mouse model. J. Neurosci. 25, 3032-3040.

55. Hooijmans, C.R., Rutters, F., Dederen, P.J., Gambarota, G., Veltien, A., van Groen, T., Broersen, L.M., Lütjohann, D., Heerschap, A., Tanila, H., and Kiliaan, A.J. (2007) Changes in cerebral blood volume and amyloid pathology in aged Alzheimer APP/PS1 mice on a docosahexaenoic acid (DHA) diet or cholesterol enriched Typical Western Diet (TWD). Neurobiol. Dis. 28, 16-29.

56. Calon, F., Lim, G.P., Yang, F., Morihara, T., Teter, B., Ubeda, O., Rostaing, P., Triller, A., Salem, N., Ashe, K.H., Frautschy, S.A., and Cole, G.M. (2004) Docosahexaenoic acid protects from dendritic pathology in an Alzheimer's disease mouse model. Neuron 43, 633-645.

57. Florent, S., Malaplate-Armand, C., Youssef, I., Kriem, B., Koziel, V., Escanye, M.-C., Fifre, A., Sponne, I., Leininger-Muller, B., Olivier, J.-L., Pillot, T., and Oster, T. (2006) Docosahexaenoic acid prevents neuronal apoptosis induced by soluble amyloid oligomers. J. Neurochem. 96, 385-395.

58. Cole, G.M., Lim, G.P., Yang, F., Teter, B., Begum, A., Ma, Q., Harris-White, M.E., and Frautschy, S.A. (2005) Prevention of Alzheimer's disease: omega-3 fatty acid and phenolic anti-oxidant interventions. Neurobiol. Aging 26(Suppl 1), 133-136.

59. Wurtman, R.J., Ulus, I.H., Cansev, M., Watkins, C.J., Wang, L., and Marzloff, G. (2006) Synaptic proteins and phospholipids are increased in gerbil brain by administering uridine plus docosahexaenoic acid orally. Brain Res. 1088, 83-92.

60. Park, I.H., Hwang, E.M., Hong, H.S., Boo, J.H., Oh, S.S., Lee, J., Jung, M.W., Bang, O.Y., Kim, S.U., and MookJung, I. (2003) Lovastatin enhances Abeta production and senile plaque deposition in female $\mathrm{Tg} 2576$ mice. Neurobiol. Aging 24, 637-643.

61. Oksman, M., Iivonen, H., Hogyes, E., Amtul, Z., Penke, B., Leenders, I., Broersen, L., Lutjohann, D., Hartmann, T., and Tanila, H. (2006) Impact of different saturated fatty acid, polyunsaturated fatty acid and cholesterol containing diets on beta-amyloid accumulation in APP/PS1 transgenic mice. Neurobiol. Dis. 23, 563-572.

62. Solfrizzi, V., Panza, F., and Capurso A. (2003) The role of diet in cognitive decline. J. Neural Transm. 110, 95-110.

63. Favrelere, S., Stadelmann-Ingrand, S., Huguet, F., De Javel, D., Piriou, A., Tallineau, C., and Durand, G. (2000) Agerelated changes in ethanolamine glycerophospholipid fatty acid levels in rat frontal cortex and hippocampus. Neurobiol. Aging 21, 653-660.

64. Yehuda, S., Rabinovitz, S., and Mostofsky, D.I. (1998) Modulation of learning and neuronal membrane composition in the rat by essential fatty acid preparation: time-course analysis. Neurochem. Res. 23, 627-634.

65. Heron, D.S., Shinitzky, M., Hershkowitz, M., and Samuel, D. (1980) Lipid fluidity markedly modulates the binding of serotonin to mouse brain membranes. Proc. Natl. Acad. Sci. U. S. A. 77, 7463-7467.

66. Delion, S., Chalon, S., Hearault, J., Guilloteau, D., Besnard, J.-C., and Durand, G. (1994) Chronic dietary-linolenic acid deficiency alters dopaminergic and serotoninergic neurotransmission in rats. J. Nutr. 124, 2466-2476.

67. Horrocks, L.A. and Yeo, Y.K. (1999) Health benefits of docosahexaenoic acid (DHA). Pharmacol. Res.40, 211-225.

68. Keli, S.O. and Feskens, E.J. (1994) Kromhout D. Fish consumption and risk of stroke. The Zutphen Study. Stroke 25, 328-332.

69. Marchioli, R., Barzi, F., Bomba, E., Chieffo, C., Di Gregorio, D., Di Mascio, R., Franzosi, M.G., Geraci, E., Levantesi, G., Maggioni, A.P., Mantini, L., Marfisi, R.M., Mastrogiuseppe, G., Mininni, N., Nicolosi, G.L., Santini, M., Schweiger, C., Tavazzi, L., Tognoni, G., Tucci, C., Valagussa, F.; GISSI-Prevenzione Investigators (2002) Early protection against sudden death by n-3 polyunsaturated fatty acids after myocardial infarction: time-course analysis of the results of the Gruppo Italiano per lo Studio della Sopravvivenza nell'Infarto Miocardico (GISSI)-Prevenzione. Circulation 105, 1897-1903.

70. Crawford, M.A., Bloom, M., Broadhurst, C.L., Schmidt, W.F., Cunnane, S.C., Galli, C., Gehbremeskel, K., Linseisen, F., Lloyd-Smith, J., and Parkington, J. (1999) Evidence for the unique function of docosahexaenoic acid during the evolution of the modern hominid brain. Lipids 34(Suppl), S39-S47.

71. Reaven, P.D., Grasse, B.J., and Tribble, D.L. (1994) Effects of linoleate-enriched and oleate-enriched diets in combination with alpha-tocopherol on the susceptibility of LDL and LDL subfractions to oxidative modification in humans. Arterioscler. Thromb. 14, 557-566.

72. Blankenhorn, D.H., Johnson, R.L., Mack, W.J., el Zein, H.A., and Vailas, L.I. (1990) The influence of diet on the appearance of new lesions in human coronary arteries. JAMA 263, 1646-1652.

73. de Lorgeril, M., Salen, P., Martin, J.L., Monjaud, I., Boucher, P., and Mamelle, N. (1998) Mediterranean dietary pattern in a randomized trial: prolonged survival and possible reduced cancer rate. Arch. Intern. Med. 158, 11811187. 
74. Ambring, A., Friberg, P., Axelsen, M., Laffrenzen, M., Taskinen, M.R., Basu, S., and Johansson, M. (2004) Effects of a Mediterranean-inspired diet on blood lipids; vascular function and oxidative stress in healthy subjects. Clin. Sci. 106, 519-525.

75. Kivipelto, M. and Solomon, A (2008) Alzheimer's disease - the ways of prevention. J. Nutr. Health Aging 12, 89S94S.

76. Solfrizzi, V., Capurso, C., D'Introno, A., Colacicco, A.M., Frisardi, V., Santamato, A., Ranieri, M., Fiore, P., Vendemiale, G., Seripa, D., Pilotto, A., Capurso, A., and Panza, F. (2008) Dietary fatty acids, age-related cognitive decline, and mild cognitive impairment. J. Nutr. Health Aging 12, 382-386.

77. Scarmeas, N., Stern, Y., Mayeux, R., Manly, J.J., Schupf, N., and Luchsinger, J.A. (2009) Mediterranean diet and mild cognitive impairment. Arch. Neurol. 66, 216-225.

78. Solfrizzi, V., Capurso, C., D'Introno, A., Colacicco, A.M., Capurso, A., and Panza, F. (2006) Whole-diet approach and risk of chronic disease: limits and advantages. J. Am. Geriatr. Soc. 54, 1800-1802.

79. Jacques, P.F. and Tucker, K.L. (2001) Are dietary patterns useful for understanding the role of diet in chronic disease? Am. J. Clin. Nutr. 73, 1-2.

80. Trichopoulou, A., Orfanos, P., Norat, T., Bueno-de-Mesquita, B., Ocké, M.C., Peeters, P.H., van der Schouw, Y.T., Boeing, H., Hoffmann, K., Boffetta, P., Nagel, G., Masala, G., Krogh, V., Panico, S., Tumino, R., Vineis, P., Bamia, C., Naska, A., Benetou, V., Ferrari, P., Slimani, N., Pera, G., Martinez-Garcia, C., Navarro, C., Rodriguez-Barranco, M., Dorronsoro, M., Spencer, E.A., Key, T.J., Bingham, S., Khaw, K.T., Kesse, E., Clavel-Chapelon, F., BoutronRuault, M.C., Berglund, G., Wirfalt, E., Hallmans, G., Johansson, I., Tjonneland, A., Olsen, A., Overvad, K., Hundborg, H.H., Riboli, E., and Trichopoulos, D. (2006) Modified Mediterranean diet and survival: EPIC-elderly prospective cohort study. BMJ 330, 1329-1330.

81. Solfrizzi, V., Frisardi, V., Capurso, C., D'Introno, A., Colacicco, A.M., Chiloiro, R., Dellegrazie, F., Di Palo, A., Capurso, A., and Panza, F. (2009) Whole-diet approach: working on a criterion validity for age-related cognitive decline and mild cognitive impairment. J. Am. Geriatr. Soc., in press.

\section{This article should be cited as follows:}

Solfrizzi, V., Frisardi, V., Capurso, C., D’Introno, A., Colacicco, A.M., Vendemiale, G., Capurso, A., and Panza, F. (2009) Dietary fatty acids and predementia syndromes. TheScientificWorldJOURNAL 9, 792-810. DOI 10.1100/tsw.2009.82. 


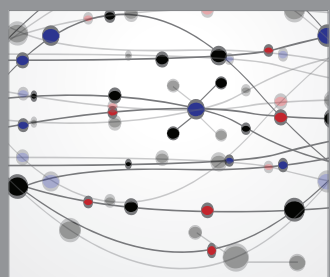

The Scientific World Journal
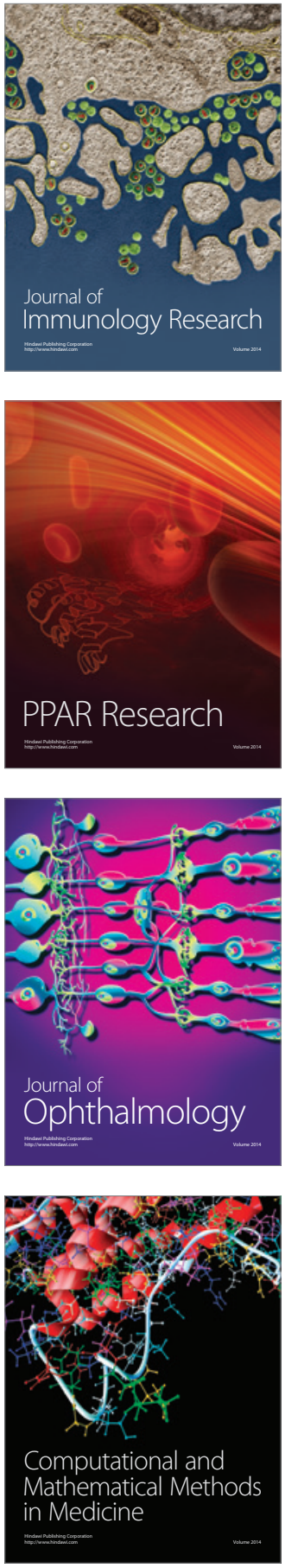

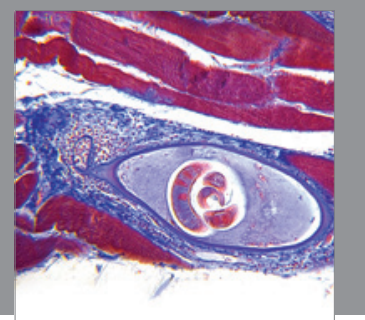

Gastroenterology

Research and Practice
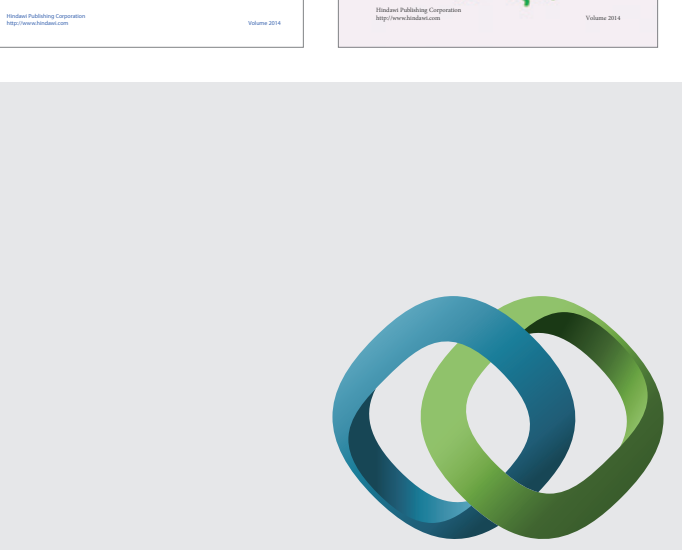

\section{Hindawi}

Submit your manuscripts at

http://www.hindawi.com
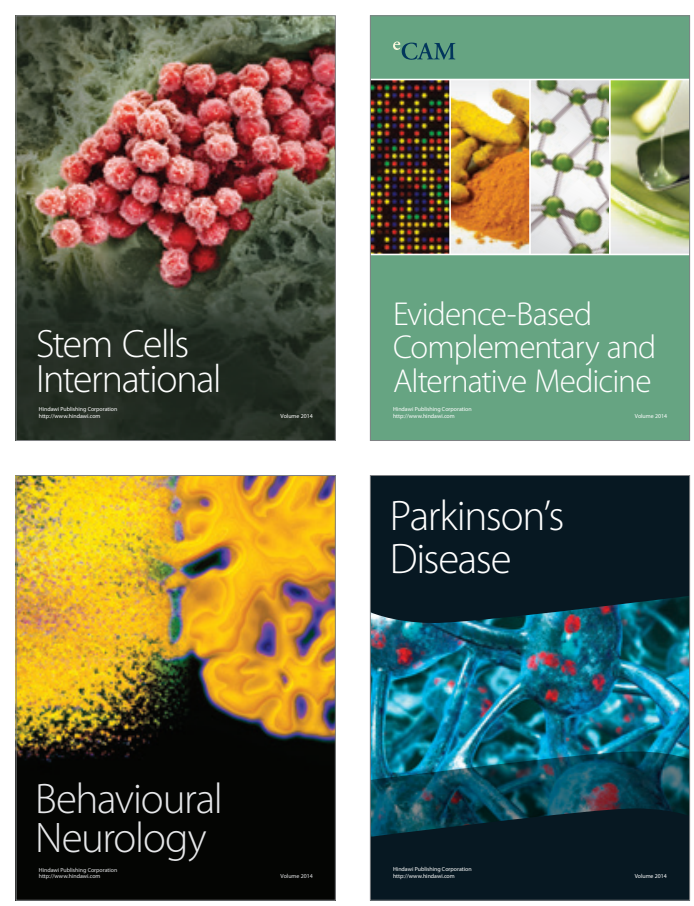

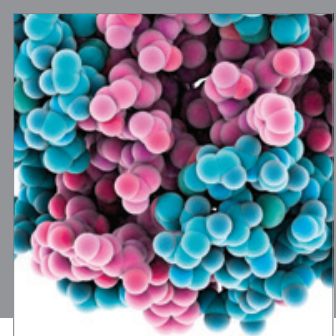

Journal of
Diabetes Research

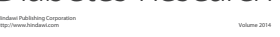

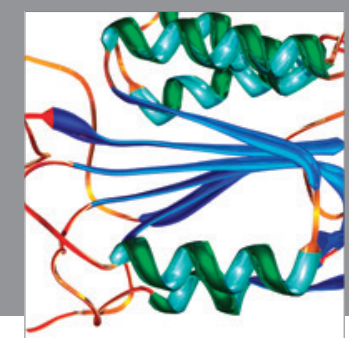

Disease Markers
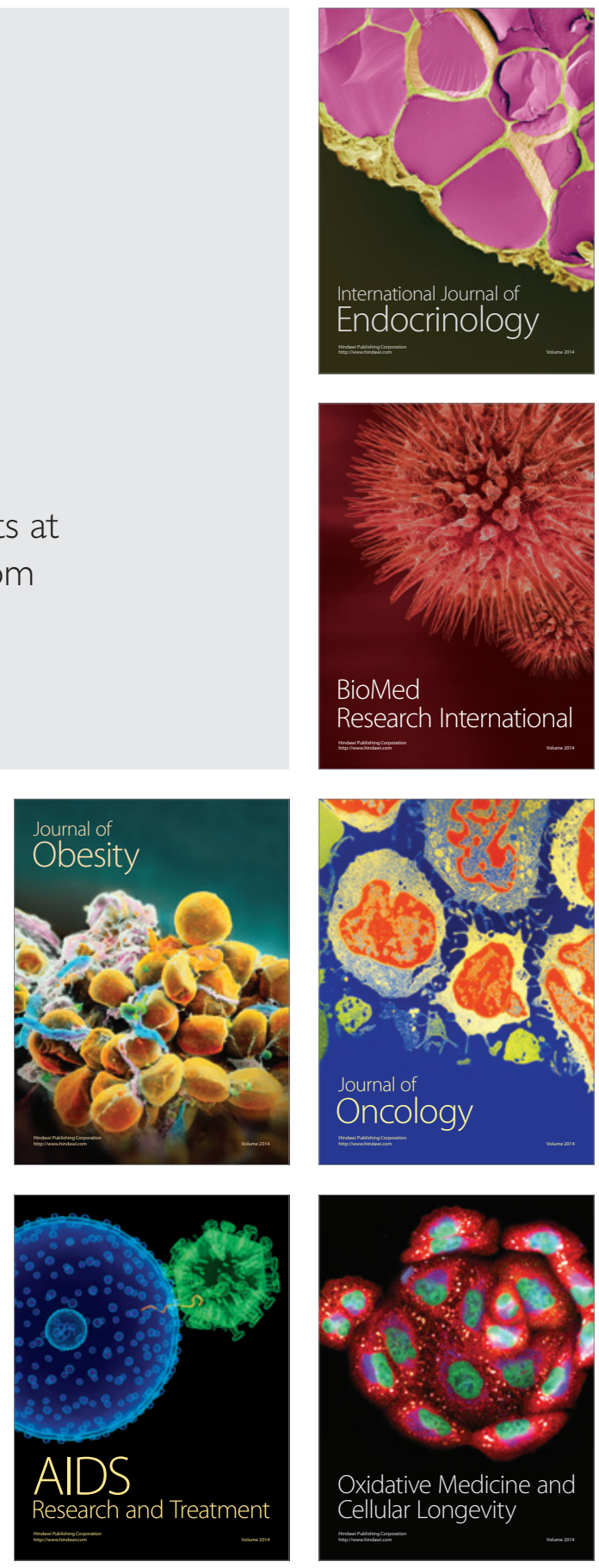